\title{
Plant carbon and water fluxes in tropical montane cloud forests
}

\author{
Sybil G. Gotsch*,1, Heidi Asbjornsen ${ }^{\dagger}$ and Gregory R. Goldsmith ${ }^{\ddagger}$ \\ * Department of Biology, Franklin and Marshall College, Lancaster, PA, USA \\ $\dagger$ Department of Natural Resources and the Environment, University of New Hampshire, Durham, NH, USA \\ ¥ Ecosystem Fluxes Group, Laboratory for Atmospheric Chemistry, Paul Scherrer Institut, Villigen, Switzerland \\ (Received 2 March 2015; revised 17 June 2016; accepted 18 June 2016; first published online 15 July 2016)
}

\begin{abstract}
Tropical montane cloud forests (TMCFs) are dynamic ecosystems defined by frequent, but intermittent, contact with fog. The resultant microclimate can vary considerably over short spatial and temporal scales, affecting the ecophysiology of TMCF plants. We synthesized research to date on TMCF carbon and water fluxes at the scale of the leaf, plant and ecosystem and then contextualized this synthesis with tropical lowland forest ecosystems. Mean light-saturated photosynthesis was lower than that of lowland forests, probably due to the effects of persistent reduced radiation leading to shade acclimation. Scaled to the ecosystem, measures of annual net primary productivity were also lower. Mean rates of transpiration, from the scale of the leaf to the ecosystem, were also lower than in lowland sites, likely due to lower atmospheric water demand, although there was considerable overlap in range. Lastly, although carbon use efficiency appears relatively invariant, limited evidence indicates that water use efficiency generally increases with altitude, perhaps due to increased cloudiness exerting a stronger effect on vapour pressure deficit than photosynthesis. The results reveal clear differences in carbon and water balance between TMCFs and their lowland counterparts and suggest many outstanding questions for understanding TMCF ecophysiology now and in the future.
\end{abstract}

Key Words: carbon cycling, ecohydrology, ecophysiology, fog-affected forests, foliar water uptake, photosynthesis, primary productivity, sap flow, transpiration, water-use efficiency

\section{INTRODUCTION}

Tropical montane cloud forests (TMCFs) are ecosystems that often experience frequent and direct contact between low-lying clouds and vegetation (i.e. fog; Bruijnzeel et al. 2011). This frequent fog alters microclimate by reducing photosynthetically active radiation (PAR) and vapour pressure deficits (VPD) while increasing the frequency and duration of leaf wetting (Bruijnzeel et al. 2011, Grubb 1977, Oliveira et al. 2014). In addition, due to altitude and typical orographic rainfall patterns, TMCFs often experience mild temperatures and high precipitation. This unique microclimate influences plant carbon (photosynthesis) and water (transpiration) exchange at the scale of the leaf and whole plant (Figure 1). When these processes are scaled to the ecosystem, the effects of microclimate can be detected in both carbon and water cycling. TMCFs are generally considered to have lower rates of leaflevel gas exchange, thus leading to lower ecosystem rates of primary productivity and transpiration as compared with their lowland counterparts (Bruijnzeel \&

\footnotetext{
${ }^{1}$ Corresponding author. Email: sybil.gotsch@fandm.edu
}

Veneklaas 1998). While TMCFs remain understudied by physiological ecologists in comparison with lowland rain forests, research efforts in the last $20 \mathrm{y}$ have intensified and now allow for a more comprehensive consideration.

To date, there has been no systematic evaluation of research on plant water and carbon relations of TMCFs, nor has the ecophysiology of TMCFs been compared and contrasted with that of tropical lowland ecosystems. We surveyed the TMCF literature for empirical measurements of carbon and water fluxes, as well as carbon- and wateruse efficiency, at the scales of the leaf, plant and ecosystem. In doing so, we specifically sought to (1) build a quantitative foundation for understanding the plant ecophysiology of TMCFs in comparison with that of lowland tropical rain forests in the context of their differing microclimates, and (2) identify outstanding research questions that can serve as the basis for future research.

\section{Approach}

Tropical montane cloud forests have been identified as occurring worldwide; however, there is currently no 

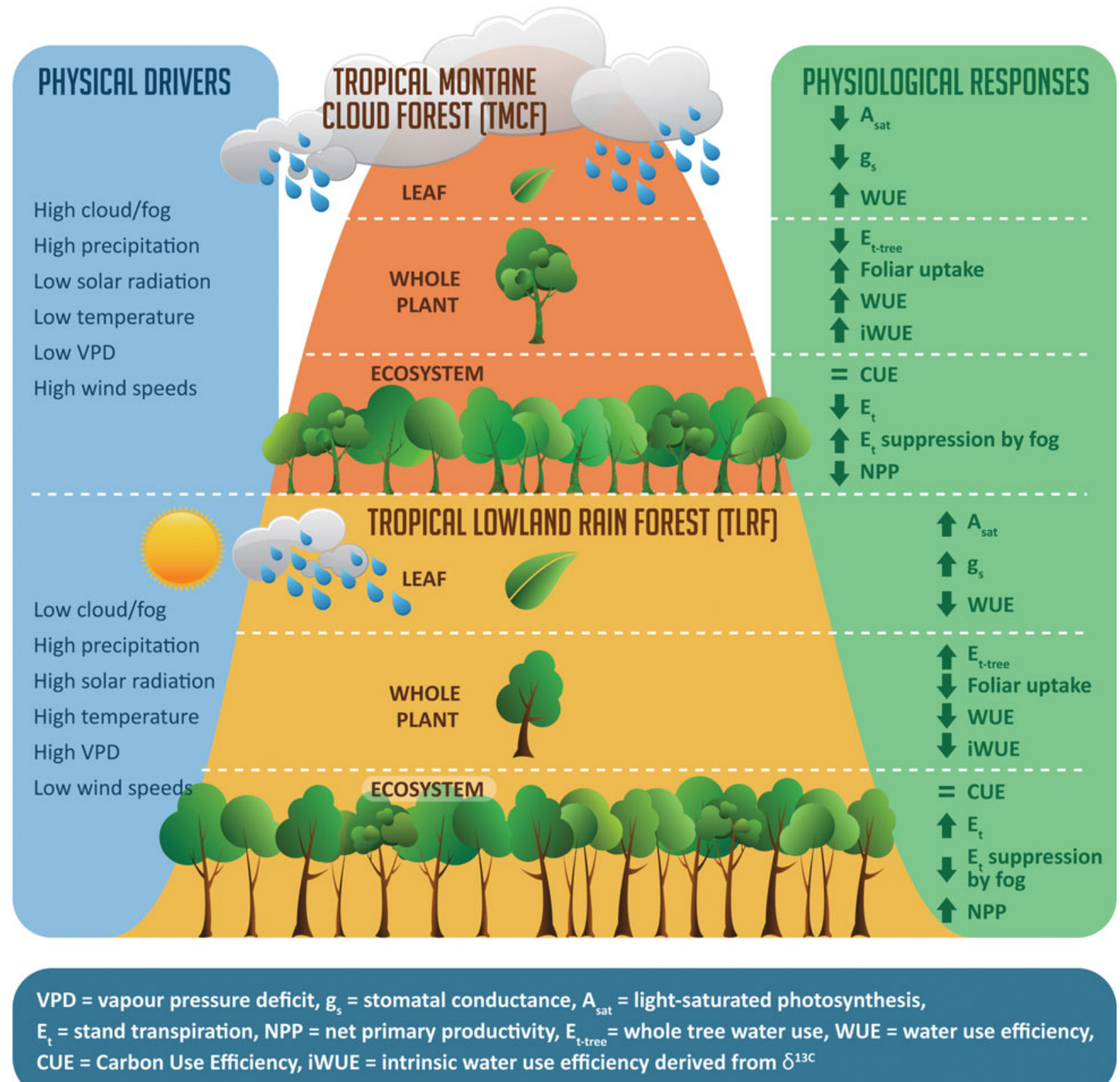

Figure 1. A generalized comparison of the environmental drivers and their corresponding impacts on carbon and water fluxes in tropical montane cloud forest (TMCF) and lowland tropical rain forest (LTRF). Drivers and response variables are depicted at the leaf, whole plant, and ecosystem scales.

standardized biophysical definition. In this review, we include research papers that the authors identified as having been conducted in TMCF and that had relevant information on plant carbon and water relations, as well as those that make note of the role of clouds in mediating a tropical montane forest's microclimate. Overall, we identified relevant data from 28 sites in Australia, Borneo, Colombia, Ecuador, Mexico, Peru, Puerto Rico, Taiwan, Hawai'i (USA) and Venezuela. The sites span an altitudinal range from 865 to $3060 \mathrm{~m}$ asl with a mean annual temperature of $14^{\circ} \mathrm{C} \pm 0.53^{\circ} \mathrm{C}$ and mean annual precipitation of $3343 \pm 282 \mathrm{~mm}$. Given the limited number of studies focused on ecophysiology, those identified herein appear to be a fair representation of TMCF. Jarvis \& Mulligan (2011), in a synthesis of TMCF biophysical conditions based on a United Nations World Conservation Monitoring Centre database, found an altitudinal range from 22 to $5005 \mathrm{~m}$ asl with a mean annual temperature of $17.7^{\circ} \mathrm{C}$ and mean annual precipitation of $2027 \mathrm{~mm}$. Wherever possible given data on a sufficient number of sites, we carried out statistical comparisons of carbon and water flux traits between 
Table 1. Mean light saturated photosynthesis and dark respiration observed in tropical montane cloud forests.

\begin{tabular}{|c|c|c|c|c|c|c|c|}
\hline $\begin{array}{l}\text { Mean } \\
\text { light-saturated } \\
\text { photosyn- } \\
\text { thesis }(\mu \mathrm{mol} \\
\left.\mathrm{m}^{-2} \mathrm{~s}^{-1}\right)\end{array}$ & $\begin{array}{l}\text { Dark respiration } \\
\left(\mu \mathrm{mol} \mathrm{m}{ }^{-2} \mathrm{~s}^{-1}\right)\end{array}$ & $\begin{array}{l}\text { Altitude } \\
\text { (m asl) }\end{array}$ & $\begin{array}{l}\text { Precip. } \\
\left(\mathrm{mm} \mathrm{y}^{-1}\right)\end{array}$ & $\begin{array}{l}\text { Temp. } \\
\left({ }^{\circ} \mathrm{C}\right)\end{array}$ & Location & $\begin{array}{l}\text { No. of } \\
\text { species }\end{array}$ & Study \\
\hline$\overline{5.5 \pm 1.7(\mathrm{SD})}$ & - & 1700 & 2714 & 18.9 & Borneo & 8 & Hikosaka et al. (2002) \\
\hline $9.1 \pm 2.4(\mathrm{SD})$ & - & $1445-1480$ & 3600 & $11-18$ & Colombia & 4 & Letts \& Mulligan (2005) \\
\hline $8.3 \pm 1.5(\mathrm{SD})$ & - & 2160 & 7000 & $11-18$ & Colombia & 4 & Letts \& Mulligan (2005) \\
\hline $6.3 \pm 1.0(\mathrm{SD})$ & - & 2400 & $1700-2700$ & 13.6 & Venezuela & 5 & Rada et al. (2009) \\
\hline $7.0 \pm 0.3(\mathrm{SE})$ & - & 3025 & 1706 & 11.1 & Peru & 5 & van de Weg (2012) \\
\hline $7.2 \pm 0.1(\mathrm{SE})$ & $0.66 \pm 0.07(\mathrm{SE})$ & 3000 & 4500 & 9 & Ecuador & 10 & Wittich et al. (2012) \\
\hline $8.0 \pm 0.5(\mathrm{SE})$ & $0.43 \pm 0.05(\mathrm{SE})$ & 1500 & 5302 & 18.8 & Peru & $15-25$ trees & $\begin{array}{c}\text { Huaraca-Huasco et al. } \\
\text { (2014) }\end{array}$ \\
\hline $6.4 \pm 0.4(\mathrm{SE})$ & $0.69 \pm 0.07(\mathrm{SE})$ & 1750 & 5302 & 17.4 & Peru & $15-25$ trees & $\begin{array}{c}\text { Huaraca-Huasco et al. } \\
\text { (2014) }\end{array}$ \\
\hline - & $0.68 \pm 0.05(\mathrm{SE})$ & 2825 & 1560 & 13.1 & Peru & $15-25$ trees & Girardin et al. (2014) \\
\hline- & $0.57 \pm 0.05(\mathrm{SE})$ & 3025 & 1560 & 11.8 & Peru & $15-25$ trees & Girardin et al. (2014) \\
\hline
\end{tabular}

tropical lowland rain forests and TMCF; however, we did not conduct an exhaustive survey of lowland forest traits.

\section{Carbon relations}

The low productivity and biomass of TMCF in comparison to the lowland forests is a longstanding observation and has been the subject of considerable research (Bruijnzeel \& Veneklaas 1998, Grubb 1971, 1977; Whitmore 1998). Although many hypotheses have been proposed regarding direct or indirect effects of climate on plant and ecosystem function, we still lack a comprehensive and mechanistic understanding of what limits the productivity of TMCFs. Leaf carbon assimilation (i.e. photosynthesis) and respiration are the physiological foundation for productivity and biomass accumulation and can thus provide insight into TMCF processes and patterns, particularly when contextualized with lowland ecosystems. Here, we summarize the available literature on photosynthesis and respiration at the scales of the leaf, plant and ecosystem.

Leaf: photosynthesis and respiration. Mean light-saturated leaf photosynthetic rates $\left(A_{\text {sat }}\right)$ measured in TMCF canopy trees and understorey shrubs range from 5.5-9.1 $\mu \mathrm{mol}$ $\mathrm{m}^{-2} \mathrm{~s}^{-1}$, with a mean of $7.2 \mu \mathrm{mol} \mathrm{m} \mathrm{m}^{-2} \mathrm{~s}^{-1}$ across the available studies (Table $1, \mathrm{n}=8$ sites in six studies). Lüttge (2007) reported a range of light-saturated photosynthesis rates across tropical forests from 13.0 to $19.0 \mu \mathrm{mol}$ $\mathrm{m}^{-2} \mathrm{~s}^{-1}$, while Wittich et al. (2012) recently reported a range from $3.7-20.3 \mu \mathrm{mol} \mathrm{m}{ }^{-2} \mathrm{~s}^{-1}$ with a mean of $10.0 \mu \mathrm{mol} \mathrm{m} \mathrm{m}^{-2} \mathrm{~s}^{-1}$ specifically from tropical lowland forests. The rates synthesized by Wittich et al. (2012) are significantly higher than those observed for TMCF trees $(\mathrm{t}=2.8, \mathrm{df}=10.2, \mathrm{P}<0.02)$. Within the TMCF dataset herein, which spans from 1445 to $3025 \mathrm{~m}$ asl, there is no evidence for a significant change in $A_{\text {sat }}$ as a function of altitude (least squares regression; $\mathrm{P}>$ 0.05). Wittich et al. (2012) found a weak, but significant decrease of $1.3 \mu \mathrm{mol} \mathrm{m}{ }^{-2} \mathrm{~s}^{-1}$ in photosynthesis for every $1000 \mathrm{~m}$ change in altitude. Although altitude serves as a proxy for changes in temperature, there are a number of other factors that may confound a strong univariate relationship with photosynthesis.

The current evidence does not necessarily imply that TMCF species (or even montane species in general) fundamentally differ in $A_{\text {sat }}$, but more likely indicates a response to limiting environmental conditions (Körner 1999). TMCFs differ in temperature, the partial pressure of $\mathrm{CO}_{2}$ in air, soil nutrient availability, and photosynthetically active radiation (PAR) and here we explore the effects of these factors on photosynthesis. Although, as noted above, temperature decreases with increasing altitude, peak rates of photosynthesis occur over a wide range of temperatures (Lloyd \& Farquhar 2008). The partial pressure of $\mathrm{CO}_{2}$ also decreases predictably $(\sim 11 \%$ per $1000 \mathrm{~m}$ altitude, although the mixing ratio of gases remains the same), reducing the amount of carbon available for assimilation (Gale 1972). However, this is compensated for by a concomitant decrease in the partial pressure of $\mathrm{O}_{2}$ and thus photorespiration, as well as an increase in $\mathrm{CO}_{2}$ diffusion. Limited available evidence from a tree species occurring along what is often considered a cloud-affected altitudinal gradient in Hawai'i suggests that increases in carboxylation capacity, in concert with changes in leaf nutrients and structure, may offset decreases in the partial pressure of $\mathrm{CO}_{2}$ and lead to similar rates of photosynthesis along the gradient (Cordell et al. 1998, 1999). Decreases in soil nutrient availability with increasing altitude 
may lead to decreases in foliar nutrient concentrations, particularly nitrogen and phosphorus (Benner \& Vitousek 2011), which are both critical for the photosynthetic machinery. However, evidence for the effects of nutrient limitation on photosynthesis along altitudinal gradients is generally mixed and needs to be carefully considered in the context of area- vs. mass-based measurements (Cordell et al. 1999, van de Weg et al. 2009, Wittich et al. 2012).

Among all the environmental conditions considered, $15-50 \%$ reductions in PAR associated with cloud immersion in TMCF are likely to exert the strongest effects on photosynthesis, leading to the development of shade-acclimated leaves (Bruijnzeel \& Veneklaas 1998, Bruijnzeel et al. 2010). This may be further compounded by light levels below that of saturation, as well as further reductions in photosynthesis occurring when those clouds also result in leaf wetting (Letts et al. 2010). Leaves on lowland trees provided with supplemental light over the course of a year demonstrated an increase in $A_{\text {sat }}$ as compared with controls (Graham et al. 2003), indicating acclimation to higher light conditions. There is a clear need for similar studies of both photosynthetic acclimation to light and ambient rates of photosynthesis in TMCFs, particularly in relation to cloud immersion and its effects on light quantity and quality.

The magnitude of leaf dark respiration in TMCFs is of equal interest to that of photosynthesis because of its critical contribution to ecosystem carbon balance. Two studies on canopy trees at four sites in Peruvian TMCFs found respiration, measured at $25^{\circ} \mathrm{C}$, to range from 0.43 to $0.69 \mu \mathrm{mol} \mathrm{m}^{-2} \mathrm{~s}^{-1}$, with a mean of $0.59 \mu \mathrm{mol} \mathrm{m}^{-2} \mathrm{~s}^{-1}$ (Girardin et al. 2014, Huaraca Huasco et al. 2014). Such values are not qualitatively different from respiration measured nearby at two lowland sites, where respiration ranged from 0.49 to $0.67 \mu \mathrm{mol} \mathrm{m}^{-2} \mathrm{~s}^{-1}$ (Malhi et al. 2014), although a comprehensive study of lowland tropical rain-forest canopy trees and lianas in Panama reported a range of 0.72 to 1.79 with a mean of 1.11 $\mu \mathrm{mol} \mathrm{m}{ }^{-2} \mathrm{~s}^{-1}$ when measured at $25^{\circ} \mathrm{C}$ (Slot et al. 2013). Standardized measurements of dark respiration among TMCFs are of great interest, particularly with respect to establishing the extent to which thermal acclimation will occur in response to warming temperatures (Vanderwel et al. 2015).

Plant and ecosystem: growth rates and primary productivity. Translating rates of leaf photosynthesis and respiration to the whole plant remains a challenge in all ecosystems. Photosynthetic assimilates can be used immediately for growth or metabolic maintenance, or stored for later use. Understanding plant carbon fluxes is further complicated by the possibility of translocation and allocation to various parts of the plant both above- and below-ground. Thus, while repeat stem diameter measurements are a common method for studying whole-plant growth rates (e.g. diameter increment; Herwitz \& Young 1994, Holder 2008, Homeier et al. 2010, Weaver et al. 1986), this approach must be treated with caution and is more appropriately incorporated into whole-ecosystem-level estimates of net primary productivity (i.e. forest growth; Clark et al. 2001a).

At the ecosystem scale, complete carbon budgets from field-based studies of TMCFs are just beginning to emerge (Girardin et al. 2014, Huaraca Huasco et al. 2014). Comprehensive and standardized approaches that facilitate insight into the components of above- and below-ground productivity are critical for building a process-based understanding of the linkages among leaf, plant and ecosystem-scale carbon relations. At present, the most commonly available estimates in TMCF are for one or more aspects of above-ground net primary productivity (NPP), particularly leaf litterfall $\left(\mathrm{NPP}_{\text {leaf }}\right)$. Mean annual $\mathrm{NPP}_{\text {leaf }}$ range from 1.11-4.12 Mg C $\mathrm{ha}^{-1} \mathrm{y}^{-1}$, with a mean of $2.23 \mathrm{Mg} \mathrm{C} \mathrm{ha}^{-1} \mathrm{y}^{-1}$ and correlate strongly with $\mathrm{NPP}_{\text {above-ground }}(\mathrm{r}=0.82$, Table 2 , $\mathrm{n}=12$ sites in nine studies). Mean annual rates of $\mathrm{NPP}_{\text {above-ground }}$, generated from estimates of woody stem and canopy production, range widely from 1.6-9.44 $\mathrm{Mg} \mathrm{C}$ ha $^{-1} \mathrm{y}^{-1}$, with a mean of $4.30 \mathrm{MgC} \mathrm{ha}^{-1} \mathrm{y}^{-1}$. An additional tropical montane cloud forest site in the Dominican Republic, using repeated estimates of aboveground biomass from allometric equations, has found negative rates of $\mathrm{NPP}_{\text {above-ground }}\left(-0.16 \mathrm{Mg} \mathrm{Cha}^{-1} \mathrm{y}^{-1}\right)$, an observation attributed to frequent wind and landslide disturbance (Sherman et al. 2012). Notably, the sites with the lowest (Hawai'i observed in Cordell et al. 1998, Raich et al. 1997) and highest $\mathrm{NPP}_{\text {above-ground }}$ (Peru observed in Huaraca Huasco et al. 2014) are also the sites with the lowest and highest light-saturated photosynthetic rates.

Both metrics of TMCF productivity have a mean $\sim 25 \%$ lower than that of lowland rain forests. A synthesis of $\mathrm{NPP}_{\text {leaf }}$ from across old-growth lowland tropical rain forests in South America reports a range of 1.46-4.74 $\mathrm{Mg} \mathrm{C} \mathrm{ha}{ }^{-1} \mathrm{y}^{-1}$ with a mean of $3.03 \mathrm{Mg} \mathrm{C} \mathrm{ha}{ }^{-1} \mathrm{y}^{-1}$ (Chave et al. 2010); this is significantly higher than TMCF (t-test; $\mathrm{t}=3.2, \mathrm{df}=14.6, \mathrm{P}<0.01$, Figure 2 ). This observation holds when scaled to $\mathrm{NPP}_{\text {above-ground }}$. A synthesis in lowland tropical forests (excluding sites $>1000 \mathrm{~m}$ asl) reported a range of $3.3-9.9 \mathrm{Mg} \mathrm{C} \mathrm{ha}^{-1}$ $\mathrm{y}^{-1}$ with a mean of $6.22 \mathrm{Mg} \mathrm{C}^{-1} \mathrm{y}^{-1}$ (Clark et al. 2001b), which is also significantly higher than TMCF (ttest; $\mathrm{t}=2.5, \mathrm{df}=20.5, \mathrm{P}=0.02$ ). While above-ground TMCF productivity appears to be distinctly lower than that of the lowlands, insights into below-ground processes remain more difficult to disentangle. Several studies have noted the possibility of a compensatory increase in $\mathrm{NPP}_{\text {root }}$ with increasing altitude (Leuschner et al. 2007), although research to date has demonstrated mixed results (Girardin et al. 2013, Moser et al. 2011). 
Table 2. Mean gross primary productivity (GPP), total above- and below-ground net primary productivity (Total NPP), carbon use efficiency (CUE), aboveground net primary productivity $\left(\mathrm{NPP}_{\text {aboveground }}\right)$ and leaf net primary productivity $\left(\mathrm{NPP}_{\text {leaf }}\right)$ observed in tropical montane cloud forests. Note that for consistency, all measurements were converted megagrams of carbon assuming that carbon is $50 \%$ of the weight of biomass.

\begin{tabular}{|c|c|c|c|c|c|c|c|c|c|}
\hline $\begin{array}{l}\overline{\mathrm{GPP}} \\
\left(\mathrm{Mg} \mathrm{Cha}^{-1} \mathrm{y}^{-1}\right)\end{array}$ & $\begin{array}{c}\text { Total NPP } \\
\left(\mathrm{Mg} \mathrm{C} \mathrm{ha}^{-1} \mathrm{y}^{1}\right)\end{array}$ & CUE & $\begin{array}{l}\mathrm{NPP}_{\text {aboveground }} \\
\left(\mathrm{Mg} \mathrm{C} \mathrm{ha}^{-1} \mathrm{y}^{-1}\right)\end{array}$ & $\begin{array}{c}\mathrm{NPP}_{\text {leaf }} \\
\left(\mathrm{Mg} \mathrm{Cha}^{-1} \mathrm{y}^{-1}\right)\end{array}$ & $\begin{array}{l}\text { Altitude } \\
\text { (m asl) }\end{array}$ & $\begin{array}{l}\text { Precip. } \\
\left(\mathrm{mm} \mathrm{y}^{-1}\right)\end{array}$ & $\begin{array}{c}\text { Temp. } \\
\left({ }^{\circ} \mathrm{C}\right)\end{array}$ & Location & Study \\
\hline- & - & - & 3.13 & 2.22 & 1615 & 2600 & $20.5^{*}$ & Jamaica & Tanner (1980) \\
\hline - & - & - & 3.02 & 2.47 & 1615 & 2600 & $19.5^{*}$ & Jamaica & Tanner (1980) \\
\hline - & - & - & 3.45 & 2 & 1570 & 2600 & $18.5^{*}$ & Jamaica & Tanner (1980) \\
\hline - & - & - & 4.49 & 2.49 & 1590 & 2600 & $19.0^{*}$ & Jamaica & Tanner (1980) \\
\hline - & - & & $1.60 \pm 0.25(\mathrm{SE})$ & $1.15 \pm 0.24(\mathrm{SE})$ & 1660 & 2570 & 13.1 & Hawaii & Raich et al. (1997) \\
\hline - & - & - & 3.9 & 2.66 & 2700 & 2085 & 13.7 & Borneo & $\begin{array}{c}\text { Kitayama \& Aiba } \\
(2002)\end{array}$ \\
\hline 16.7 & 5.4 & 0.32 & 3.7 & 1.11 & 1050 & 4200 & 18.8 & Puerto Rico & $\begin{array}{l}\text { Weaver \& Murphy } \\
\text { (1990), }\end{array}$ \\
\hline 9.0 & 4.1 & 0.45 & 1.44 & 1.37 & 3060 & 4500 & 9.4 & Ecuador & $\begin{array}{c}\text { Moser et al. (2011), } \\
\text { Leuschner et al. } \\
\text { (2013) }\end{array}$ \\
\hline $21.8 \pm 0.90(\mathrm{SE})$ & $7.05 \pm 0.39(\mathrm{SE})$ & 0.32 & $5.34 \pm 0.33(\mathrm{SE})$ & $1.96 \pm 0.28$ (SE) & 2825 & 1560 & 13.1 & Peru & Girardin et al. (2014) \\
\hline $25.9 \pm 1.08$ (SE) & $8.04 \pm 0.47$ (SE) & 0.31 & $5.88 \pm 0.31(\mathrm{SE})$ & $2.52 \pm 0.18(\mathrm{SE})$ & 3025 & 1560 & 11.8 & Peru & Girardin et al. (2014) \\
\hline $38.6 \pm 1.96(\mathrm{SE})$ & $11.94 \pm 0.47(\mathrm{SE})$ & 0.31 & $9.44 \pm 0.68(\mathrm{SE})$ & $4.12 \pm 0.18(\mathrm{SE})$ & 1500 & 5302 & 18.8 & Peru & $\begin{array}{c}\text { Huaraca Huasco et al. } \\
\qquad(2014)\end{array}$ \\
\hline $32.3 \pm 1.60(\mathrm{SE})$ & $7.92 \pm 0.38(\mathrm{SE})$ & 0.24 & $6.19 \pm 1.92(\mathrm{SE})$ & $2.63 \pm 0.17(\mathrm{SE})$ & 1750 & 5302 & 17.4 & Peru & $\begin{array}{c}\text { Huaraca Huasco et al. } \\
\text { (2014) }\end{array}$ \\
\hline
\end{tabular}




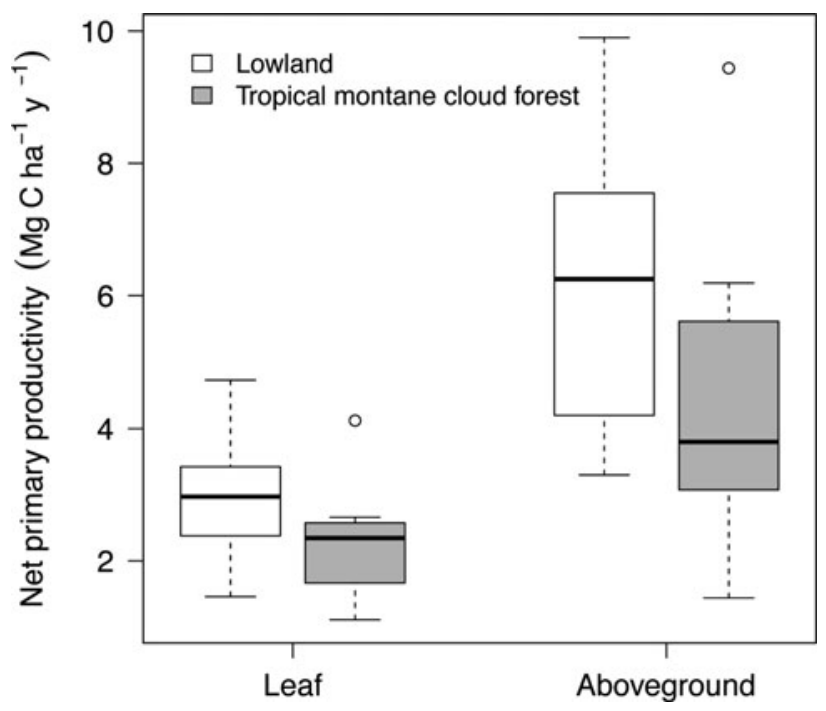

Figure 2. A comparison of lowland tropical rain forest and tropical montane cloud forest (TMCF) leaf and aboveground net primary productivity generated by comparing lowland syntheses from Clark et al. (2001b) and Chave et al. (2010) with data compiled herein on TMCF.

The decreased above-ground net primary productivity observed in TMCF relative to lowland rain forests may be attributed to other factors besides solely a reduction in photosynthesis driven by light (or other factors discussed above) and thus a limited source of carbon. An alternative possibility is that productivity is also limited by the lack of carbon consumption and maintenance activity (e.g. sink dynamics). For instance, it has been proposed that limits on cell division by temperature, water and nutrients occur prior to limits on photosynthesis (Fatichi et al. 2014). On temperate mountains, there is evidence that temperature serves as the limiting factor for growth and that there may exist an excess of stored carbon (non-structural carbohydrates) available for use by plants (Körner 2003). However, studies of non-structural carbohydrate storage are only beginning to emerge for tropical lowland forests (Würth et al. 2005). Ultimately, a combination of observational and experimental approaches is likely necessary to help resolve the carbon source-sink dynamics that link leaf and plant level growth with patterns observed at the scale of the ecosystem.

\section{Water relations}

High precipitation and frequent cloud and fog cover inevitably influence water balance and storage in TMCFs. In general, at the leaf and plant level, TMCFs transpire less than lowland tropical rain forests (Bruijnzeel et al. 2011, Figure 1). While this pattern may adequately characterize annual patterns of transpiration, intra-annual patterns of water use in TMCFs may be more difficult to characterize due to the highly variable micrometeorological conditions that many TMCFs experience. Factors influencing evaporative demand, including wind speed, relative humidity, temperature and radiation can all vary over short time scales in the TMCF and these fluctuations will in turn affect water fluxes (Giambelluca et al. 2009). Thus, despite lower stand-level averages, the maximum reported rates of water use in TMCFs are comparable with lowland forests (Feild \& Holbrook 2000, Santiago et al. 2000, Zotz 1998).

Leaf: stomatal conductance. Mean rates of stomatal conductance $\left(g_{s}\right)$ for canopy trees across TMCFs range from $60-561 \mathrm{mmol} \mathrm{m}^{-2} \mathrm{~s}^{-1}$, with a mean of $239 \mathrm{mmol}$ $\mathrm{m}^{-2} \mathrm{~s}^{-1}$ (Table 3, $\mathrm{n}=8$ sites in seven studies). Two of these studies quantified $g_{s}$ under saturating light conditions and report somewhat higher values (Cordero 1999, Letts et al. 2010), while the other studies reported daytime averages. Average $g_{s}$ across these TMCF sites is $40 \%$ lower than the average $g_{s}$ reported from a lowland rain forest in Panama $\left(370 \pm 14 \mathrm{mmol} \mathrm{m}^{-2} \mathrm{~s}^{-1}\right.$, Meinzer et al. 1993, 1997). Midday decreases in stomatal conductance $\left(g_{s}\right)$ on clear days have been observed in three TMCFs, indicating that despite generally wet conditions, either soil water supply or atmospheric demand limits transpiration (Cavelier 1990, Gotsch et al. 2014a, Rada et al. 2009). For instance, $g_{s}$ dropped from approximately $400 \mathrm{mmol} \mathrm{m}^{-2}$ $\mathrm{s}^{-1}$ in the early morning to $100 \mathrm{mmol} \mathrm{m}^{-2} \mathrm{~s}^{-1}$ by midday in a Columbian TMCF (Cavelier 1990). Midday depression was also observed in Maui, following $1 \mathrm{~d}$ without rain, although the overall rates were lower; early morning to midday $g_{s}$ varied from $100 \mathrm{mmol} \mathrm{m} \mathrm{m}^{-2} \mathrm{~s}^{-1}$ to just 40 $\mathrm{mmol} \mathrm{m} \mathrm{m}^{-2} \mathrm{~s}^{-1}$ (Gotsch et al. 2014a). During the midday depression, vapour pressure deficit (VPD) exceeded 1.0 $\mathrm{kPa}$. Correlations between VPD and transpiration have been found across a number of ecosystems, highlighting the important role of evaporative demand on plant-water relations (Bucci et al. 2004, Dawson et al. 2007, Eller et al. 2015, Gotsch et al. 2014a, b; Motzer et al. 2005). Despite frequent precipitation, plant available soil water also varies greatly in TMCF ecosystems and is likely to play an important role in transpiration (Eller et al. 2015, Jarvis \& Mulligan 2011).

Plant: individual water-use. The few studies that have quantified whole plant water use in the TMCFs demonstrate a great deal of variability among sites although comparisons among sites are difficult since different sized trees were studied (Appendix 1). One of the few studies to quantify volumetric sap flow in dominant TMCF trees estimated an average daily transpiration rate of $24.7 \mathrm{~L} \mathrm{~d}^{-1}$ over a relatively wet 10 -d period in Maui, Hawai'i (Gotsch et al. 2014a). Clouds were often 
Table 3. Stomatal conductance observed in canopy trees in tropical montane cloud forests.

\begin{tabular}{|c|c|c|c|c|c|}
\hline $\begin{array}{l}\text { Stomatal conductance } \\
\left(\mathrm{mmol} \mathrm{m}^{-2} \mathrm{~s}^{-1}\right)\end{array}$ & $\begin{array}{l}\text { Altitude } \\
\text { (m asl) }\end{array}$ & $\begin{array}{c}\text { Precipitation } \\
\left(\mathrm{mm} \mathrm{y}^{-1}\right)\end{array}$ & Temp. $\left({ }^{\circ} \mathrm{C}\right)$ & Location & Study \\
\hline $100-425^{*}$ & 865 & - & - & Colombia & Cavelier (1990) \\
\hline $401 \pm 40(\mathrm{SE})$ & 1051 & 4210 & - & Puerto Rico & Cordero (1999) \\
\hline $\begin{array}{l}\text { sunny/level: } 233 \pm 17 \text { (SE) } \\
\text { sunny/sloped: } 219 \pm 32(\mathrm{SE}) \\
\text { cloudy/level: } 177 \pm 24 \text { (SE) } \\
\text { cloudy/sloped: } 187 \pm 25 \text { (SE) }\end{array}$ & 1200 & 5000 & 14.5 & Maui & Santiago et al. (2000) \\
\hline $561 \pm 255(\mathrm{SE})$ & $1445-1480$ & 3600 & $11-18$ & Colombia & Letts \& Mulligan (2005) \\
\hline $459 \pm 45(\mathrm{SE})$ & 2160 & 7000 & $11-18$ & Colombia & Letts \& Mulligan (2005) \\
\hline $161 \pm 84(\mathrm{SD})$ & $1950-1975$ & 2067 & 15.5 & Equator & Motzer et al. (2005) \\
\hline $\begin{array}{l}\text { wet season: } 71 \pm 9(\mathrm{SE}) ; \\
\quad \text { dry season: } 60 \pm 7(\mathrm{SE})\end{array}$ & 2400 & $1700-2700$ & 13.6 & Venezuela & Rada et al. (2009) \\
\hline $105 \pm 9(\mathrm{SE})$ & $2109-2231$ & $3500-5000$ & 10.5 & Maui & Gotsch et al. (2014b) \\
\hline
\end{tabular}

* No mean reported.

passing through the study site and cloudy periods were interspersed with short periods with clear skies. During this 10-d period, transpiration ranged from 5.5 to 63 $\mathrm{L} \mathrm{d}^{-1}$. In an elfin forest in Costa Rica, transpiration rates of less than $2 \mathrm{~L} \mathrm{~d}^{-1}$ were reported (Feild \& Holbrook 2000). This high-altitude site is characterized by more frequent fog and precipitation than lower altitude TMCFs (Bruijnzeel \& Hamilton 2000). The suppression of transpiration due to fog and resultant low leaf to air VPDs and leaf wetting has been documented in a number of studies and is probably the cause for such low average daily transpiration in elfin cloud forest (AlvaradoBarrientos et al. 2014, Goldsmith et al. 2013, Gotsch et al. 2014b).

A great deal of variation has also been documented in lowland tropical rain forests; however, rates of daily water use tend to be higher than in TMCFs. During a dry season period in lowland Panama, sap flow ranged from 46.6 to $379 \mathrm{~L} \mathrm{~d}^{-1}$ in $18-35-\mathrm{m}$ trees (Goldstein et al. 1998). This can be explained by the combined changes in microclimate, including greater VPD and reduced leafwetting events. Very few studies have calculated wholeplant transpiration in TMCFs; greater research efforts are necessary to understand seasonal, within-site and among-site variation in whole-plant transpiration.

The presence of fog and resultant leaf wetting can also facilitate the direct absorption of water into leaves, providing an additional source of moisture availability (i.e. foliar water uptake or FWU, see review by Oliveira et al. 2014). In a TMCF in Mexico, canopy wetness due to fog and drizzle in the dry season facilitated FWU that resulted in the recovery of $4-16 \%$ of the dry-seasontranspired water (Gotsch et al. 2014b). Cloud water interception (CWI) at this site (i.e. stand-level throughfall and stemflow) is approximately $6-8 \%$ of the total dryseason rainfall (Holwerda et al. 2010, Muñoz-Villers et al. 2012). In TMCFs with more frequent fog occurrence, the importance of FWU in plant water balance will likely be greater. A recent study on epiphytes in the TMCF of Costa Rica, where the CWI is approximately $30 \%$ of rainfall (Hager \& Dohrenbush 2011), found that FWU in canopy epiphytes resulted in the recovery of $37 \%$ to almost $100 \%$ of the equivalent water transpired during a month in the misty/windy transition season (Gotsch et al. 2015). While FWU can offset transpiration losses in the TMCF, the microclimate can vary greatly diurnally, leading to periods with high VPD (Holwerda et al. 2010). High evaporative demand, especially at night, can lead to water loss via partially open stomates, which will greatly affect whole-plant water use (Dawson et al. 2007). In Veracruz, Mexico, nighttime transpiration contributed $14-24 \%$ of the dry-season branch-level water loss (Gotsch et al. 2014b). Foliar uptake and nighttime transpiration are two processes that are likely important components of the TMCF water cycle; additional research is needed to understand the role that these processes play in plant water status and ecosystem water balance.

Ecosystem: stand transpiration. The high variation in leaf and plant water-use is also evident at the stand level. Estimates of stand-level transpiration $\left(\mathrm{E}_{\mathrm{t}}\right)$ range from $c$. $65 \mathrm{~mm} \mathrm{y}^{-1}$ to $1232 \mathrm{~mm} \mathrm{y}^{-1}$ in Hawaiian montane cloud forests alone (Giambelluca et al. 2009, Santiago et al. 2000). Mean $\mathrm{E}_{\mathrm{t}}$ among 10 sites was $630 \mathrm{~mm} \mathrm{y}^{-1}$ (Table 4). The estimate of TMCF $E_{t}$ is on the high end of the data reviewed by Bruijnzeel et al. (2011), who reported a range of $E_{t}$ from $385 \mathrm{~mm} \mathrm{y}^{-1}$ to $646 \mathrm{~mm} \mathrm{y}^{-1}$. They include data from 15 studies that they define as TMCF and report a negative relationship between altitude and $E_{t}$, which was attributed to changes in temperature, radiation and cloudiness. The highest $\mathrm{E}_{\mathrm{t}}$ occurred in so-called 'lower montane cloud forest' and the lowest rates occur in high-altitude 'elfin forest' (Bruijnzeel et al. 2011). In some 
Table 4. Stand-level transpiration observed in tropical montane cloud forests.

\begin{tabular}{|c|c|c|c|c|c|}
\hline $\begin{array}{l}\mathrm{E}_{\mathrm{t}} \text { (stand-level tree } \\
\text { transpiration) }\end{array}$ & $\begin{array}{l}\text { Altitude } \\
\text { (m asl) }\end{array}$ & $\begin{array}{l}\text { Precipitation } \\
\left(\mathrm{mm} \mathrm{y}^{-1}\right)\end{array}$ & Temp. $\left({ }^{\circ} \mathrm{C}\right)$ & Location & Study \\
\hline $558 \mathrm{~mm} \mathrm{y}^{-1}$ & 2350 & 3125 & $9-14$ & Venezuela & Ataroff \& Rada (2000) \\
\hline $0.05-1.17 \mathrm{~mm} \mathrm{~d}^{-1} *$ & 1200 & 5000 & 14.5 & Maui & Santiago et al. (2000) \\
\hline $812 \mathrm{~mm} \mathrm{y}^{-1}$ & $1265-1420$ & 1837 & 19.7 & Thailand & Tanaka et al. $(2003,2011)$ \\
\hline $353 \mathrm{~mm} \mathrm{y}^{-1}$ & 1560 & 8100 & - & Australia & McJannet et al. (2007) \\
\hline $1232 \mathrm{~mm} \mathrm{y}^{-1}$ & 1219 & 2500 & - & Hawaii (USA) & Giambelluca et al. (2009) \\
\hline $415 \mathrm{~mm} \mathrm{y}^{-1}$ & 1450 & 6000 & - & Costa Rica & $\begin{array}{l}\text { Referenced in Bruijnzeel } \\
\text { et al. (2011) }\end{array}$ \\
\hline $919 \mathrm{~mm} \mathrm{y}^{-1}$ & 2030 & 2140 & - & Ecuador & $\begin{array}{c}\text { Referenced in Bruijnzeel } \\
\text { et al. (2011) }\end{array}$ \\
\hline $674 \mathrm{~mm} \mathrm{y}^{-1}$ & 900 & 4450 & - & Puerto Rico & $\begin{array}{l}\text { Referenced in Bruijnzeel } \\
\text { et al. (2011) }\end{array}$ \\
\hline $645 \pm 50 \mathrm{~mm} \mathrm{y}^{-1}$ & 2180 & $2000-3000$ & 14.3 & Mexico & $\begin{array}{c}\text { Alvarado-Barrientos et al. } \\
\text { (2014) }\end{array}$ \\
\hline
\end{tabular}

*Range of daily estimates made on level- and sloped-sites.

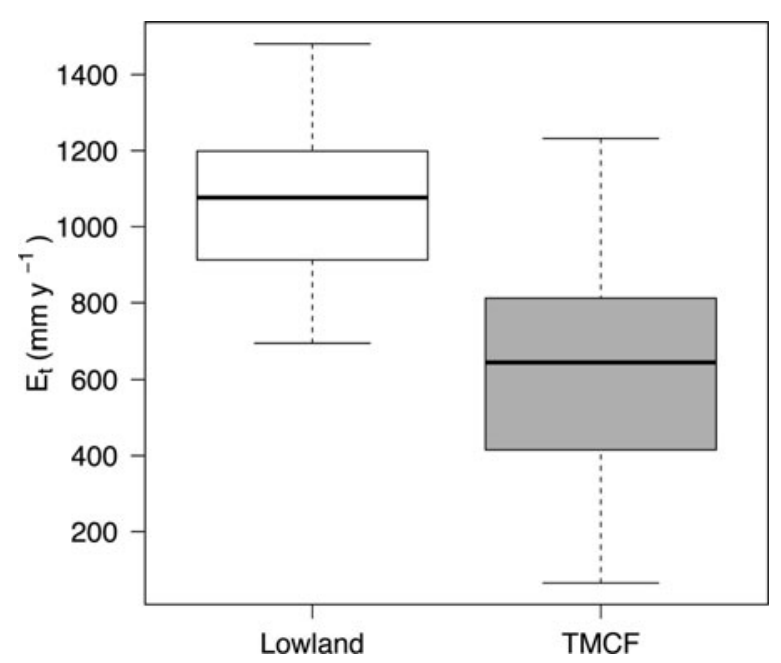

Figure 3. A comparison of lowland tropical rain forest and tropical montane cloud forest (TMCF) annual stand-level transpiration generated by comparing lowland syntheses from McJannet et al. (2007) with data compiled herein on TMCF.

of the studies included, particularly at lower altitudes, the authors do not explicitly identify the site as a TMCF, and as a result we do not include them herein. McJannet et al. (2007) synthesized $E_{t}$ values from lowland tropical forests and including their own data, $\mathrm{E}_{\mathrm{t}}$ ranged from 693.5-1131 $\mathrm{mm} \mathrm{y}^{-1}$ with an average of $957 \mathrm{~mm} \mathrm{y}^{-1}$. Given this, TMCF $\mathrm{E}_{\mathrm{t}}$ is significantly lower than lowland tropical rain forests $(\mathrm{t}=3.1, \mathrm{df}=14.3, \mathrm{P}=0.007$; Figure 3$)$.

Stand-level studies in TMCFs do provide insight into the environmental drivers of the observed variation. Over a 5-d period in Maui, Hawai'i, transpiration varied by almost an order of magnitude within sites (Santiago et al. 2000). In sloped sites, transpiration varied from 0.17 to $1.17 \mathrm{~mm} \mathrm{~d}^{-1}$; transpiration also varied greatly in level sites, although rates were lower $\left(0.05-0.31 \mathrm{~mm} \mathrm{~d}^{-1}\right)$. During this experiment, radiation varied considerably due to passing cloud cover, which resulted in large variation in VPD. On average, sites in slope areas experienced three to four times more stand-level transpiration than in level, waterlogged areas, a difference attributed to a reduction in leaf area in the level sites (Table 4, Santiago et al. 2000). Daily rates of $E_{t}$ vary greatly in different TMCF locations. $\mathrm{E}_{\mathrm{t}}$ in an Australian TMCF was $1.1 \mathrm{~mm} \mathrm{~d}^{-1}$, while a Mexican TMCF was $1.7 \mathrm{~mm} \mathrm{~d}^{-1}$, translating to a considerable annual difference $(353 \mathrm{~mm}$ and $645 \mathrm{~mm}$, respectively: Alvarado-Barrientos et al. 2014, McJannet et al. 2007). Differences in annual precipitation between these two sites $(8100 \mathrm{~mm}$ for Australia and 2000$3000 \mathrm{~mm}$ for Mexico) are substantial and may correlate with additional differences in microclimate including canopy wetness and cloud inundation, which would lead to greater suppression in $\mathrm{E}_{\mathrm{t}}$ at the Australian site. The aforementioned studies all estimated $E_{t}$ using sapflow methods, which apply heat to the plant stem and trace its diffusion to estimate flow rates. Using another methodology, eddy covariance, researchers in a TMCF in Ecuador estimated annual $\mathrm{E}_{\mathrm{t}}$ to be $471 \mathrm{~mm}$, which is greater than that found in TMCFs at higher altitudes in Puerto Rico and Costa Rica (Bruijnzeel et al. 2011, Holwerda 2005), but similar to $E_{t}$ calculated with sap flow in Australia and Mexico (Alvarado-Barrientos et al. 2014, McJannet et al. 2007).

Ultimately, while large-scale differences in $\mathrm{E}_{\mathrm{t}}$ may correlate with altitude, a great deal of variability in $E_{t}$ likely occurs within a given site. Extreme variation in topography, slope and aspect is characteristic of TMCFs. Variation in these physical features of the environment will in turn affect canopy microclimate and soil properties. As a result, even within a very narrow range of altitude, stand-level transpiration can vary widely. Such variation, from the level of the leaf to that of the stand within sites, has largely been unexplored (but see Berry et al. 2016, Santiago et al. 2000). 
Table 5. Mean leaf-level water use efficiency observed in tropical montane cloud forests.

\begin{tabular}{|c|c|c|c|c|c|c|c|}
\hline $\begin{array}{l}\text { Mean WUE } \\
\left(\mu \text { mol CO } \mathrm{CO}_{2} \text { per }\right. \\
\mathrm{mmol} \mathrm{H}_{2} \mathrm{O} \\
\left.\mathrm{m}^{-2} \mathrm{~s}^{-1}\right)\end{array}$ & $\begin{array}{l}\text { Altitude } \\
\text { (m asl) }\end{array}$ & $\begin{array}{l}\text { Precipitation } \\
\left(\mathrm{mm} \mathrm{y}^{-1}\right)\end{array}$ & Temp. $\left({ }^{\circ} \mathrm{C}\right)$ & Location & $\begin{array}{l}\text { No. of } \\
\text { species }\end{array}$ & Study & Notes \\
\hline $2.7 \pm 0.2(\mathrm{SE})$ & 1051 & 4210 & & Puerto Rico & 1 & Cordero (1999) & $\begin{array}{c}\text { Potted } \\
\text { saplings }\end{array}$ \\
\hline $3.5 \pm 0.5(\mathrm{SE})$ & $1445-1480$ & 3600 & $11-18$ & Colombia & 4 & Letts \& Mulligan (2005) & \\
\hline $5.2 \pm 0.5(\mathrm{SE})$ & 2160 & 7000 & $11-18$ & Colombia & 4 & Letts \& Mulligan (2005) & \\
\hline $3.6 \pm 0.6(\mathrm{SE})$ & 2400 & $1700-2700$ & 13.6 & Venezuela & 5 & Rada et al. (2009) & Wet season \\
\hline $2.4 \pm 0.2(\mathrm{SE})$ & 2400 & $1700-2700$ & 13.6 & Venezuela & 5 & Rada et al. (2009) & Dry season \\
\hline
\end{tabular}

\section{Carbon-water relations}

The measures of plant carbon and water use considered above are inextricably coupled through gas exchange processes occurring at the leaf surface, whereby $\mathrm{CO}_{2}$ uptake for photosynthesis and simultaneous water loss via transpiration under changing environmental conditions are balanced. This coupling can be considered through measurements of the efficiency of gas exchange processes, in terms of both water use efficiency (WUE; $\mathrm{CO}_{2}$ assimilation per unit water loss) and carbon use efficiency (CUE; growth per unit $\mathrm{CO}_{2}$ assimilation). WUE can be expressed at the leaf, whole-plant and ecosystem scales, whereas CUE is generally considered at the ecosystem scale. The determination of these metrics requires information on both carbon and water relations, ideally recorded simultaneously at the same temporal and spatial scales, but the number of studies that have explicitly calculated WUE and CUE is relatively few compared with those that have considered only carbon or only water fluxes (e.g. those reviewed above). Below, we review the available information on WUE and CUE reported for TMCFs to date.

Leaf: WUE. The few studies that have measured WUE in TMCFs range from $2.7-5.2 \mu \mathrm{mol} \mathrm{mmol}{ }^{-1}$, with a mean of $3.5 \mu \mathrm{mol} \mathrm{mmol}^{-1}$ (Table $5, \mathrm{n}=5$ sites in four studies). Letts \& Mulligan (2005) assessed light-saturated WUE for plants growing in less-cloudy lower montane TMCF and cloudier upper montane TMCF, and found significantly higher WUE in canopy trees and understorey shrubs (5.2 and $5.1 \mu \mathrm{mol} \mathrm{mmol}{ }^{-1}$, respectively) at the cloudier site compared with canopy trees and understorey shrubs (3.5 and $4.1 \mu \mathrm{mol} \mathrm{mmol}{ }^{-1}$ ) at the less cloudy site. This was attributed to lower vapour pressure deficit driven by leaf temperature in the cloudy site, rather than a strong change in $\mathrm{c}_{\mathrm{i}} / \mathrm{c}_{\mathrm{a}}$. Studies from lowland tropical rain forests also generally report lower plant WUE values compared with TMCF species, ranging from 1.4-4.0 $\mu \mathrm{mol} \mathrm{mmol}^{-1}$ (Cernusak et al. 2007, Cunningham 2005, Vargas \& Cordero 2013).
Given the high degree of variability in the TMCF microclimate, WUE can also be expected to vary within a given site over short temporal and spatial scales. Unfortunately, studies that have explicitly examined WUE variability in relation to topographical, seasonal, or daily variability in microclimate conditions in TMCFs are especially scarce. Cordero (1999) collected gas-exchange measurements on potted saplings of Cecropia schreberiana exposed to two contrasting natural wind regimes in elfin cloud forest in the Luquillo Experimental Forest in Puerto Rico. WUE was approximately $2.8 \mu \mathrm{mol} \mathrm{mmol}^{-1}$, with no significant difference observed between windexposed and wind-protected plants. Similarly, Sobrado (2003), working with $\delta^{13} \mathrm{C}$, found no differences in WUE between the wet and dry seasons. However, based on studies from other regions, it is likely that factors such as exposure to wind (Nagano et al. 2013), fog occurrence and associated changes in VPD, solar radiation, nutrient availability (Negret et al. 2013, Santiago \& Dawson 2014, Vasey et al. 2012), and soil moisture availability related to edaphic or topographic features (Craven et al. 2013, Rada et al. 2009), will influence plant water-carbon tradeoffs and, ultimately, WUE. More detailed studies aimed at capturing within-site variability are needed across a range of different TMCFs to better elucidate these relationships between microclimate conditions and WUE.

While variation in altitude and the associated microclimate conditions may explain large-scale patterns of WUE in TMCFs, substantial within-site variation may also occur due to differences among species in their physiological strategies and growth patterns (Table 5). Studies that have examined WUE across plant species that are common to different successional stages (i.e. early versus late successional sites) in TMCFs have generally reported lower WUE in early compared with latesuccessional species (Rada et al. 2009, Sobrado 2003). This trend is consistent with findings for tropical lowland rain forests (Bonal et al. 2007, Nogueira et al. 2004, Vargas \& Cordero 2013). Sobrado (2003) compared $\delta^{13} \mathrm{C}$ for pioneer and mature forest species occurring in a lower montane tropical forest in Venezuela. Results showed more negative $\delta^{13} \mathrm{C}$ for the mature forest species 
$(-29.02 \pm 0.28 \%)$ than the pioneer species $(-25.64 \pm$ $0.42 \%$ VPDB), suggesting more conservative water use by mature species. Wittich et al. (2012) also suggests that the range in WUE among species analysed within each altitude (e.g. 1000, 2000 and 3000 m a.s.l.) is greater than the range between the three zones, consistent with earlier observations about the high degree of withinecosystem variability in water and carbon fluxes. Rada et al. (2009) assessed WUE in four tree species and a climber with canopies in the upper strata of a cloud forest in the Venezuelan Andes during the wet and dry seasons. They reported a relatively large range of WUE between 1.79 and $5.58 \mu \mathrm{mol} \mathrm{mmol}{ }^{-1}$, and explained these differences based on species differences in physiological strategies to balance deficits with carbon gain. The two species with higher WUEs were considered to depend on strict (conservative) stomatal control, while other species exhibited relatively high water use under drier conditions in support of more opportunistic growth strategies. How such variability translates into patterns of WUE is of particular interest because of the potential for insights regarding how plants regulate gas-exchange processes in response to changing environmental conditions.

Ecosystem: WUE and CUE. To our knowledge, there are currently no ecosystem WUE estimates available for TMCFs. Ecosystem-level estimates of WUE require more complex approaches which are often prohibitive in TMCF regions, either due to the complex terrain (precluding the deployment of eddy covariance flux towers due to lack of sufficient fetch) or due to the tremendously high species diversity (posing challenges to sap flux-based measurements due to the extensive instrumentation requirements). A global review by Fernández-Martinez et al. (2014) on resource-use efficiencies among different biomes derived from GPP and actual evapotranspiration data, suggested a global convergence in mean resourceuse efficiencies. Among these estimates, WUE did not differ statistically among forest types due to high variability.

The few studies that have assessed CUE for TMCFs, located in six different regions, indicate a remarkable degree of similarity across diverse sites, with values ranging between 0.24 to 0.45 , with a mean of 0.33 (Table 5). Interestingly, this range in CUE for TMCFs is similar to that reported across a series of 10 lowland rain-forest plots (range from $0.32-0.46$ with a mean of 0.39; Malhi et al. 2015), as well as in a global synthesis of tropical broadleaved forests (range from 0.33-0.48 with a mean of 0.38; Fernández-Martinez et al. 2014). This may suggest a convergence of CUE across different tropical ecosystems. Nevertheless, determining whether these trends in WUE and CUE hold for a greater range of TMCF sites awaits future research on this topic.

\section{DISCUSSION}

Our synthesis of TMCF plant carbon and water fluxes identified a number of trends (Figure 1). With respect to plant carbon relations, research to date suggests that average light-saturated photosynthesis is lower in TMCFs than in lowland rain forests. This pattern is likely due to differences in microclimatic factors in tropical mountains suppressing photosynthesis rather than a lower intrinsic biochemical capacity of TMCF plants (van de Weg et al. 2012). Lower net leaf photosynthesis may in turn translate into lower overall net primary productivity in TMCFs relative to lowland rain forests. With respect to plant water relations, average rates of transpiration at the level of the leaf, plant and stand are also generally lower than in lowland rain-forest sites. However, the range of leaf-level conductance in TMCFs overlapped with rates in lowland rain-forest sites, while whole-plant and ecosystem-level estimates were consistently lower in TMCF. WUE tends to increase with altitude due to the TMCF generally having lower evaporative demand than lowland rain forests. Given these observations, we now identify key outstanding questions in tropical montane cloud forest plant carbon and water relations:

\section{Are TMCF plants light-limited? Research to date} demonstrates that mean light-saturated photosynthesis is approximately $25-30 \%$ lower in TMCF than in tropical lowland forests. However, the effects of clouds and cloud immersion on photosynthesis and in turn, growth and primary productivity, remain largely unresolved (Alton 2008). While clouds reduce PAR, they also increase the ratio of diffuse to direct radiation such that more consistent light penetrates the canopy (Gu et al. 2002). As a result, an increase in ecosystem carbon exchange has been observed on cloudy relative to clear days in several temperate ecosystems (Gu et al. 2002, Hollinger et al. 1994, Urban et al. 2012, but see Alton 2008). Moreover, these changes are driven by clear changes in photosynthetic efficiency, including a lower photosynthetic light compensation point (Hollinger et al. 1994, Law et al. 2002, Urban et al. 2007) and a higher apparent quantum yield (Dengel \& Grace 2010, Gu et al. 2003, Still et al. 2009). These changes thus facilitate an increase in photosynthesis per unit incident light on cloudy days up until saturating light levels. However, while the net effect of a $10-50 \%$ reduction in TMCF PAR is more likely to control photosynthetic rates than changes in photosynthetic light use efficiency, studies that systematically compare photosynthetic rates as a function of varying cloud intensity in montane cloud forests are rare (Letts \& Mulligan 2005, Reinhardt \& Smith 2008). An experimental approach in a lowland rain forest has previously demonstrated that leaves of a canopy 
tree species were acclimated to lower light and that supplemental light increased net photosynthesis, as well as plant water use (Graham et al. 2003). Manipulative experiments at the scale of the leaf and observations of $\mathrm{CO}_{2}$ fluxes at the scale of the ecosystem, complemented by simple but complete information on net annual PAR, would serve as compelling approaches to resolving the extent to which TMCF plants are light-limited.

2. What are the relative roles of plant water supply and demand in regulating TMCF water balance and how important is fog for ecosystem function? Despite abundant research establishing relationships between evaporative demand and rates of transpiration (Alvarado-Barrientos et al. 2014, Goldsmith et al. 2013, Gotsch et al. 2014b), we still lack a clear understanding of the relative roles of soil and ground water availability, as well as fog water availability and evaporative demand, in controlling rates of transpiration (but see Berry et al. 2016, Darby et al. 2016, Eller et al. 2015). For instance, in a number of TMCFs, fog has been shown to reduce transpiration, lead to additional water inputs to the soil, and directly improve plant water status via foliar water uptake (AlvaradoBarrientos et al. 2014, Burgess \& Dawson 2004, Dawson 1998, Eller et al. 2015, Goldsmith et al. 2013, Gotsch et al. 2014a, b; Gotsch et al. 2015). However, the extent to which foliar water uptake influences ecosystem-level water balance and the degree to which a loss of foliar water uptake due to changes in climate would influence plant and ecosystem-level carbon and water fluxes is unknown. If projected changes in atmospheric conditions lead to increased evaporative demand, transpiration may increase and less of this lost water will be recovered via foliar water uptake. Such changes will inevitably affect plant and stand-level water loss in the TMCF, although the magnitude of these changes could be mediated by concomitant changes in species' WUE and CUE. Understanding the relative importance of these drivers under current conditions will help us understand how projected changes in climate may exacerbate or diminish the role of atmospheric and soil-based drivers for plant and ecosystem water use. A combination of observational and experimental approaches will be needed across a number of TMCF ecosystems to tease apart the importance of these environmental drivers.

\section{How will changes in plant carbon or water relations associated} with increasing $\mathrm{CO}_{2}$ translate to WUE? A central focus in climate change research over the past several decades has been to determine the potential for plants to acclimate to increases in atmospheric $\mathrm{CO}_{2}$ concentration via changes in their photosynthetic and stomatal regulation of carbon and water fluxes. Much of this interest lies in the possibility that stimulation of photosynthetic rates at higher atmospheric $\mathrm{CO}_{2}$ concentrations could lead to both higher WUE and hence ecosystem productivity, thereby providing a feedback mechanism for increasing the terrestrial $\mathrm{CO}_{2}$ sink, as well as improving plant resilience to water stress (Franks et al. 2013).

The combination of dendrochronology with $\delta^{13} \mathrm{C}$ analysis provides a particularly powerful approach to assessing historical relationships between atmospheric $\mathrm{CO}_{2}$ concentration and intrinsic water use efficiency (iWUE) over long timescales and could provide great insight into responses of TMCF species to recent changes in climate. In general, studies conducted in tropical rain forests suggest large increases in iWUE in response to increasing atmospheric $\mathrm{CO}_{2}$ (Cernusak et al. 2013, van der Sleen et al. 2015). However, these trends will also be influenced by changes in VPD (which are less well known), such that if leaf temperature increases due to decreasing $g_{s}$, VPD may increase and thereby dampen (but likely not eliminate) the increase in WUE (Cernusak et al. 2013). For example, in the study by Bonal et al. (2011), herbarium samples of two common tropical rain-forest species in the Guiana Shield were analysed over a 200year time period for $\delta^{13} \mathrm{C}$ and $\delta^{18} \mathrm{O}$. Based on model results, they reported an increase in iWUE over recent decades by $23.1-26.6 \%$. These results agree with findings from other forests globally (Peñuelas \& Azcón-Bieto 1992, Saurer et al. 2014). However, emerging evidence suggests that these increases in iWUE in response to rising atmospheric $\mathrm{CO}_{2}$ concentrations may not be accompanied by increases in $\mathrm{CO}_{2}$ assimilation and growth, with a 'saturation effect' on productivity likely due to countervailing effects of other limiting resources, such as moisture or nutrients (GómezGuerrero et al. 2013, Levesque et al. 2014, Peñuelas et al. 2011, van der Sleen et al. 2015). The study by GómezGuerrero et al. (2013), which assessed stem increment growth and $\delta^{13} \mathrm{C}$ in high-altitude cloud-affected forests in central Mexico, is most similar to TMCF and found that $\mathrm{CO}_{2}$-induced increases in iWUE were not sufficient to counteract impacts of warming-induced drought stress on growth. More research is needed to disentangle the interactive effects of climate change-induced increases in temperature, moisture stress and nutrient limitation on iWUE and $\mathrm{CO}_{2}$ assimilation to better understand the potential consequences for long-term productivity and resilience of TMCFs to climate extremes.

TMCF water and carbon relations in a changing climate. Changes in TMCF cloud immersion are projected as a function of changing land and sea surface temperatures associated with anthropogenic change (Karmalkar et al. 2008, 2011; Lawton et al. 2001, Pounds et al. 1999, 2006; Still et al. 1999). Direct observations of changes in tropical montane cloud immersion are currently limited (but 
see Richardson et al. 2003 for a temperate analogue). However, changes in temperature and precipitation for tropical mountains, which are clearly linked, are more readily available. Tropical mountains are projected to be particularly vulnerable to changes in temperature and precipitation, with current climate regimes possibly disappearing by 2100 (Williams et al. 2007). Significant increases in temperature are projected to be further enhanced at high altitudes, while precipitation is projected to be more variable in general, with net increases or decreases possible depending on the location (Karmalkar et al. 2008, 2011; Urrutia \& Vuille 2009). As with many places in the tropics, long-term observations of these trends in TMCF are limited. However, consistent with modelling projections (Karmalkar et al. 2011), Pounds et al. (1999, 2006) has observed increases in the number of days without rain as a function of increasing temperatures in Costa Rican TMCF. Taken together, such climatic changes indicate clear increases in temperature that will have associated effects on VPD, likely decreases in cloud immersion further changing VPD and also affecting light availability, and associated, but poorly understood changes in precipitation.

The extent of these changes, and their impacts on tropical montane cloud-forest carbon and plant water relations, remains to be seen. However, the questions posed above can help guide the next generation of research. Studying the extent to which TMCF plants are light-limited will provide the basis for understanding how changes in clouds will affect leaf-level photosynthesis and ecosystem productivity. Studying the relative roles of plant water supply and demand in regulating TMCF water balance will provide the basis for understanding how changes in both precipitation and clouds will change leaf, plant and ecosystem water balance, while a specific focus on fog can elucidate whether it plays a critical role in alleviating water deficits through foliar water uptake. And finally, studying water use efficiency places climate change in context with concomitant increases in $\mathrm{CO}_{2}$ and its observed effects on plant function. Will the tropical montane cloud forests of the future function similarly, will they function more like tropical lowland rain forests, or will they not be able to withstand the rapid projected changes? Increased research efforts are needed to understand the degree to which anthropogenic climate change will affect the resilience of these unique ecosystems.

\section{ACKNOWLEDGEMENTS}

The authors would like to thank P. Martin for the invitation to contribute this review. We thank Z.C. Berry and two anonymous reviewers for feedback on this manuscript. G.R. Goldsmith acknowledges funding from the European Community's Seventh Framework Programme (FP7/2007-2013) under grant agreement number 290605 (COFUND: PSI-FELLOW). S.G. Gotsch acknowledges funding from Franklin and Marshall College. Floortje van Osch produced the conceptual model shown in Figure 1.

\section{LITERATURE CITED}

ALTON, P. B. 2008. Reduced carbon sequestration in terrestrial ecosystems under overcast skies compared to clear skies. Agricultural and Forest Meteorology 148:1641-1653.

ALVARADO-BARRIENTOS, M. S., HOLWERDA, F., ASBJORNSEN, H., DAWSON, T. E. \& BRUIJNZEEL, L. A. 2014. Suppression of transpiration due to cloud immersion in a seasonally dry Mexican weeping pine plantation. Agricultural and Forest Meteorology 186:1225.

ATAROFF, M. \& RADA, F. 2000. Deforestation impact on water dynamics in a Venezuelan Andean cloud forest. Ambio 29:440-444. BENNER, J. W. \& VITOUSEK, P. M. 2011. Cyanolichens: a link between the phosphorus and nitrogen cycles in a Hawaiian montane forest. Journal of Tropical Ecology 28:73-81.

BERRY, Z. C., GOTSCH, S. G., HOLWERDA, F., MUÑOZ-VILLERS, L. E. \& ASBJORNSEN, H. 2016. Slope position influences vegetationatmosphere interactions in a tropical montane cloud forest. Agricultural and Forest Meteorology 221:207-218.

BONAL, D., BORN, C., BRECHERT, C., COSTE, S., MARCON, E., ROGGY, J. C. \& GUEHL, J. M. 2007. The successional status of tropical rainforest tree species is associated with differences in leaf carbon isotope discrimination and functional traits. Annals of Forest Science 64:169-176.

BONAL, D., PONTON, S., LE THIEC, D., RICHARD, B., NINGRE, N., HÉRAULT, B., OGÉE, J., GONZALEZ, S., PIGNAL, M., SABATIER, D. \& GUFHI, J.-M. 2011. Leaf functional response to increasing atmospheric $\mathrm{CO} 2$ concentrations over the last century in two northern Amazonian tree species: a historical $\delta 13 \mathrm{C}$ and $\delta 180$ approach using herbarium samples. Plant, Cell and Environment 34:1332-1334.

BRUIJNZEEL, L. A. \& HAMILTON, L. S. 2000. Decision time for cloud forests. IHP Humid Tropics Programme Series No. 13, UNESCO Division of Water Sciences, Paris. 41 pp.

BRUIJNZEEL, L. A. \& VENEKLAAS, E. J. 1998. Climatic conditions and tropical montane cloud forest productivity: the fog has not lifted yet. Ecology 79:3-9.

BRUIJNZEEL, L. A., SCATENA, F. N. \& HAMILTON, L. S. (eds). 2010. Tropical montane cloud forests: science for conservation and management. Cambridge University Press, Cambridge. 768 pp.

BRUIJNZEEL, L. A., MULLIGAN, M. \& SCATENA, F. N. 2011. Hydrometeorology of tropical montane cloud forests: emerging patterns. Hydrological Processes 25:465-498.

BUCCI, S. J., SCHOLZ, F. G., GOLDSTEIN, G., MEINZER, F. C., HINOJOSA, J. A., HOFFMANN, W. A. \& FRANCO, A. C. 2004. Processes preventing nocturnal equilibration between leaf and soil 
water potential in tropical savanna woody species. Tree Physiology 24:1119-1127.

BURGESS, S. S. O. \& DAWSON, T. E. 2004. The contribution of fog to the water relations of Sequoia sempervirens (D. Don): foliar uptake and prevention of dehydration. Plant Cell and Environment 27:10231034.

CAVELIER, J. 1990. Tissue water relations in elfin cloud forest tree species of Serrania de Macuira, Guajira, Colombia. Trees - Structure and Function 4:155-163.

CERNUSAK, L. A., ARANDA, J., MARSHALL, J. D. \& WINTER, K. 2007. Large variation in whole-plant water-use efficiency among tropical tree species. New Phytologist 173:294-305.

CERNUSAK, L. A., WINTER, K., DALLING, J. W., HOLTUM, J. A. M., JARAMILLO, C., KORNER, C., LEAKEY, A. D. B., NORBY, R. J., POULTER, B., TURNER, B. L. \& WRIGHT, S. J. 2013. Tropical forest responses to increasing atmospheric $\mathrm{CO}_{2}$ : current knowledge and opportunities for future research. Functional Plant Biology 40:531551.

CHAVE, J., NAVARRETE, D., ALMEIDA, S., ALVAREZ, E., ARAGÃO, L. E. O. C., BONAL, D., CHÂTELET, P., SILVA-ESPEJO, J. E., GORET, J. Y., VON, HILDEBRAND, P., JIMÉNEZ, E., PATIÑO, S., PEÑUELA, M. C., PHILLIPS, O. L., STEVENSON, P. \& MALHI, Y. 2010. Regional and seasonal patterns of litterfall in tropical South America. Biogeosciences 7:43-55.

ClARK, D. A., BROWN, S., KICKLIGHTER, D. W., CHAMBERS, J. Q., THOMLINSON, J. R. \& NI, J. 2001a. Measuring net primary production in forests: concepts and field methods. Ecological Applications 11:356-370.

CLARK, D. A., BROWN, S., KICKLIGHTER, D. W., CHAMBERS, J. Q., THOMLINSON, J. R., NI, J. \& HOLLAND, E. A. 2001b. Net primary production in tropical forests: an evaluation and synthesis of existing field data. Ecological Applications 11:371-384.

CORDELL, S., GOLDSTEIN, G., MUELLER-DOMBOIS, D., WEBB, D. \& VITOUSEK, P. M. 1998. Physiological and morphological variation in Metrosideros polymorpha, a dominant Hawaiian tree species, along an altitudinal gradient: the role of phenotypic plasticity. Oecologia 113:188-196.

CORDELL, S., GOLDSTEIN, G., MEINZER, F. C. \& HANDLEY, L. L. 1999. Allocation of nitrogen and carbon in leaves of Metrosideros polymorpha regulates carboxylation capacity and $\delta 13 \mathrm{C}$ along an altitudinal gradient. Functional Ecology 13:811-818.

CORDERO, R. A. 1999. Ecophysiology of Cecropia schreberiana saplings in two wind regimes in an elfin cloud forest: growth, gas exchange, architecture and stem biomechanics. Tree Physiology 19:153-163.

CRAVEN, D., HALL, J. S., ASHTON, M. A. \& BERLYN, G. P. 2013. Wateruse efficiency and whole-plant performance of nine tropical tree species at two sites with contrasting water availability in Panama. Trees 27:639-653.

CUNNINGHAM, S. C. 2005. Photosynthetic responses to vapour pressure deficit in temperate and tropical evergreen rainforest trees of Australia. Oecologia 142:521-528.

DARBY, A., DRAGUliC, D., GLUNK, A. \& GOTSCH, S. G. 2016. Habitat moisture drives transpiration and foliar water uptake in a tropical montane cloud forest canopy. Oecologia in press. doi: 10.1007/s00442-016-3659-5.
DAWSON, T. E. 1998. Fog in the California redwood forest: ecosystem inputs and use by plants. Oecologia 117:476-485.

DAWSON, T. E., BURGESS, S. S. O., TU, K. P., RA, R. S., SANTIAGO, L. S., FISHER, J. B., SIMONIN, K. A. \& AMBROSE, A. R. 2007. Nighttime transpiration in woody plants from contrasting ecosystems. Tree Physiology 27:561-575.

DENGEL, S. \& GRACE, J. 2010. Carbon dioxide exchange and canopy conductance of two coniferous forests under various sky conditions. Oecologia 164:797-808.

ELLER, C. B., BURGESS, S. O. \& OLIVEIRA, R. S. 2015. Environmental controls in water use patterns of a tropical cloud forest tree species, Drimys braciliensis (Winteraceae). Tree Physiology 35:387399.

FATICHI, S., LEUZINGER, S. \& KÖRNER, C. 2014. Moving beyond photosynthesis: from carbon source to sink-driven vegetation modeling. New Phytologist 201:1086-1095.

FEILD, T. S. \& HOLBROOK, N. M. 2000. Xylem sap flow and stem hydraulics of the vesselless angiosperm Drimys granadensis (Winteraceae) in a Costa Rican elfin forest. Plant Cell and Environment 23:1067-1077.

FERNÁNDEZ-MARTÍNEZ, M., VICCA, S., JANSSENS, I. A., LUYSSAERT, S., CAMPIOLI, M., SARDANS, J., ESTIARTE, M. \& PEÑUELAS, J. 2014. Spatial variability and controls over biomass stocks, carbon fluxes, and resource-use efficiencies across forest ecosystems. Trees 28:597-611.

FRANKS, P. J., ADAMS, M. A., AMTHOR, J. S., BARBOUR, M. M., BERRY, J. A., ELLSWORTH, D. S., FARQUHAR, G. D., GHANNOUM, O., LLOYD, J., MCDOWELL, N., NORBY, R. J., TISSUE D. T. \& VON CAEMMERER S. 2013. Sensitivity of plants to changing atmospheric $\mathrm{CO}_{2}$ concentration: from the geological past to the next century. New Phytologist 197:1077-1094.

GALE, J. 1972. Availability of carbon dioxide for photosynthesis at high altitudes: theoretical considerations. Ecology 53:494-497.

GIAMBELLUCA, T. W., MARTIN, R. E., ASNER, G. P., HUANG, M. Y. \& MUDD, R. G. 2009. Evapotranspiration and energy balance of native wet montane cloud forest in Hawai'i. Agricultural and Forest Meteorology 149:230-243.

GIRARDin, C. A., ARAGÃO, L. E. O. C., MALHI, Y., HUARACA, HUASCO, W., METCALFE, D. B., DURAND, L., MAMANI, M., SILVAESPEJO, J. E. \& WHITTAKER, R. J. 2013. Fine root dynamics along an elevational gradient in tropical Amazonian and Andean forests. Global Biogeochemical Cycles 27:252-264.

GIRARDIN, C. A. J., ESPEJOB, J. E. S., DOUGHTY, C. E., HUASCO, W. H., METCALFE, D. B., DURAND-BACA, L., MARTHEWS, T. R., ARAGÃO, L. E. O. C., FARFÁN-RIOS, W., GARCÍA-CABRERA, K., HALLADAY, K., FISHER, J. B., GALIANO-CABRERA, D. F., HUARACA-QUISPE, L. P., ALZAMORA-TAYPE, I., EGUILUZ-MORA, L., SALINAS-REVILLA, N., SILMAN, M. R., MEIR, P. \& MALHI, Y. 2014. Productivity and carbon allocation in a tropical montane cloud forest in the Peruvian Andes. Plant Ecology and Diversity 7:107-123.

GOLDSMith, G. R., MATZKE, N. J. \& DAWSON, T. E. 2013. The incidence and implications of clouds for cloud forest plant water relations. Ecology Letters 16:307-314.

GOLDSTEIN, G., ANDRADE, F. C., MEINZER, F. C., HOLBROOK, N. M., CAVELIER, J., JACKSON, P. \& CELIS, A. 1998. Stem water storage 
and diurnal patterns of water use in tropical forest canopy trees. Plant Cell and Environment 21:397-406.

GÓMEZ-GUERRERO, A., SILVA, L. C. R., BARRERA-REYES, M., KISHCHUK, B., VELÁZQUEZ-MARTÍNEZ, A., MARTÍNEZTRINIDAD, T., PLASCENCIA-ESCALANTE, F. O. \& HORWATH, W. R., 2013. Growth decline and divergent tree ring isotopic composition $\left(\delta^{13} \mathrm{C}\right.$ and $\left.\delta^{18} \mathrm{O}\right)$ contradict predictions of $\mathrm{CO}_{2}$ stimulation in high altitudinal forests. Global Change Biology 19:1748-1758.

GOTSCH, S. G., CRAUSBAY, C. S., GIAMBELLUCA, T. W., WEINTRAUB, A. E., LONGMAN, R. J., ASBJORNSEN, H., HOTCHKISS, S. C. \& DAWSON, T. E. 2014a. Water relations and microclimate around the upper limit of a cloud forest in Maui, Hawai' $i$. Tree Physiology 34:766-777.

GOTSCH, S. G., ASBJORNSEN, H., HOLWERDA, F., GOLDSMITH, G. R., WEINTRAUB, A. E. \& DAWSON, T. E. 2014b. Foggy days and dry nights determine crown-level water balance in a seasonal tropical montane cloud forest. Plant Cell and Environment 37:261272.

GOTSCH, S. G., NADKARNI, N., DARBY, A., GLUNK, A., DIX, M., DAVIDSON, K. \& DAWSON, T. E. 2015. Life in the treetops: ecophysiological strategies of canopy epiphytes in a tropical montane cloud forest. Ecological Monographs 85:393-412.

GRAHAM, E. A., MULKEY, S., KITAJIMA, K., NG, P. \& WRIGHT, S. J. 2003. Cloud cover limits net $\mathrm{CO}_{2}$ uptake and growth of a rainforest tree during tropical rainy seasons. Proceedings of the National Academy of Sciences USA 100:572-576.

GRUBB, P. J. 1971. Interpretation of the 'Massenerhebung' effect on tropical mountains. Nature 229:44-45.

GRUBB, P. J. 1977. Control of forest growth and distribution on wet tropical mountains: with special reference to mineral nutrition. Annual Review of Ecology and Systematics 8:83-107.

GU, L., BALDOCCHI, D., VERMA, S. B., BLACK, T. A., VESALA, T., FALGE, E. M. \& DOWTY, P. R. 2002. Advantages of diffuse radiation for terrestrial ecosystem productivity. Journal of Geophysical Research 107(D6):1-23.

GU, L., BALDOCCHI, D. D., WOFSY, S. C., MUNGER, J. W., MICHALSKY, J. J., URBANSKI, S. P. \& BODEN, T. A. 2003. Response of a deciduous forest to the Mount Pinatubo eruption: enhanced photosynthesis. Science 299:2035-2038.

HAGER, A. \& DOHRENBUSCH, A. 2011. Hydrometeorology and structure of tropical montane cloud forests under contrasting biophysical conditions in Northwestern Costa Rica. Hydrological Processes 25:392-401.

HERWITZ, S. R. \& YOUNG, S. S. 1994. Mortality, recruitment, and growth rates of montane tropical rain forest canopy trees on Mount Bellenden-Ker, Northeast Queensland, Australia. Biotropica 26:350361.

HIKOSAKA, K., NAGAMATSU, D., ISHII, H. S. \& HIROSE, T. 2002. Photosynthesis-nitrogen relationships in species at different altitudes on Mount Kinabalu, Malaysia. Ecological Research 17:305-313.

HOLDER, C. 2008. Diameter growth and decline in a tropical montane cloud forest of the Sierra de las Minas, Guatemala. Journal of Tropical Forest Science 20:292-299.

HOLLINGER, D. Y., KELLIHER, F. M., BYERS, J. N., HUNT, J. E., MCSEVENY, T. M. \& WEIR, P. L. 1994. Carbon dioxide exchange between an undisturbed old-growth temperate forest and the atmosphere. Ecology 75:134-150.

HOLWERDA, F. 2005. Water and energy budgets of rain forests along an elevation gradient under maritime tropical conditions. Ph.D. dissertation, VU University Amsterdam, Amsterdam. 167 pp.

HOLWERDA, F., BRUIJNZEEL, L. A., MUÑOZ-VILLERS, L. E., EQUINA, M. \& ASBJORNSEN, H. 2010. Rainfall and cloud water interception in mature and secondary lower montane cloud forests of central Veracruz, Mexico. Journal of Hydrology 384:84-96.

HOMEIER, J., BRECKLE, S.-W., GÜNTER, S., ROLLENBECK, R. T. \& LEUSCHNER, C. 2010. Tree diversity, forest structure and productivity along altitudinal and topographical gradients in a species-rich Ecuadorian montane rain forest. Biotropica 42:140148.

HUARACA HUASCO, W., GIRARDIN, C. A. J., DOUGHTY, C. E., METCALFE, D. B., BACA, L. D., SILVA-ESPEJO, J. E., CABRERA, D. G., ARAGÃO, L. E. O. C., DAVILA, A. R., MARTHEWS, T. R., HUARACA-QUISPE, L. P., ALZAMORA-TAYPE, I., MORA, L. E., FARFÁN-RIOS, W., CABRERA, K. G., HALLADAY, K., SALINASREVILLA, N., SILMAN, M. R., MEIR, P. \& MALHI, Y. 2014. Seasonal production, allocation and cycling of carbon in two mid-elevation tropical montane forest plots in the Peruvian Andes. Plant Ecology and Diversity 7:1-18.

JARVIS, A. \& MULLIGAN, M. 2011. The climate of cloud forests. Hydrological Processes 25:327-343.

KITAYAMA, K. \& AIBA, S. 2002. Ecosystem structure and productivity of tropical rain forest along altitudinal gradients with contrasting soil phosphorus pools on Mount Kinabalu, Borneo. Journal of Ecology 90:37-51.

KARMALKAR, A. V., BRADLEY, R. S. \& DIAZ, H. F. 2008. Climate change scenario for Costa Rican montane forests. Geophysical Research Letters 35:L11702.

KARMALKAR, A. V., BRADLEY, R. S. \& DIAZ, H. F. 2011. Climate change in Central America and Mexico: regional climate model validation and climate change projections. Climate Dynamics 37:605-629.

KÖRNER, C. 1999. Alpine plant life. (Second edition). Springer, Berlin. $345 \mathrm{pp}$.

KÖRNER, C. 2003. Carbon limitation in trees. Journal of Ecology 91:417.

LAW, B. E., FALGE, E., GU, L. V., BALDOCCHI, D. D., BAKWIN, P., BERBIGIER, P., DAVIS, K., DOLMAN, A. J., FALK, M. \& FUENTES, J.D. 2002. Environmental controls over carbon dioxide and water vapor exchange of terrestrial vegetation. Agricultural and Forest Meteorology 113:97-120.

LAWTON, R. O., NAIR, U. S., PIELKE, R. A. \& WELCH, R. M. 2001. Climatic impact of tropical lowland deforestation on nearby montane cloud forests. Science 294: 584-587.

LETTS, M. G. \& MULLIGAN, M. 2005. The impact of light quality and leaf wetness on photosynthesis in north-west Andean tropical montane cloud forest. Journal of Tropical Ecology 21:549-557.

LETTS, M. G., MULLIGAN, M., RINCÓN-ROMERO, M. E. \& BRUIJNZEEL, L. A. 2010. Environmental controls on photosynthetic rates of lower montane cloud forest vegetation in south-western Colombia. Pp. 465-478 in Bruijnzeel, L. A., Scatena, F. N. \& Hamilton, L. S. (eds.). 
Tropical montane cloud forests: science for conservation and management. Cambridge University Press, Cambridge.

LEUSCHNER, C., MOSER, G., BERTSCH, C., RÖDERSTEIN, M. \& HERTEL, D. 2007. Large altitudinal increase in tree root/shoot ratio in tropical mountain forests of Ecuador. Basic and Applied Ecology 8:219230.

LEUSCHNER, C., ZACH, A., MOSER, G., HOMEIER, J., GRAEFE, S., HERTEL, D., WITTICH, B., SOETHE, N., IOST, S., RÖDERSTEIN, M., HORNA, V. \& WOLF, K. 2013. The carbon balance of tropical mountain forests along an altitudinal transect. Pp. 117-139 in Bendix, J., Beck, E., Bräuning, A., Makeschin, F., Mosandl, R., Scheu, S. \& Wilcke, W. (eds.). Ecosystem services, biodiversity and environmental change in a tropical mountain ecosystem of south Ecuador. Springer, Berlin.

LEVESQUE, M., SIEGWOLF, R., SAURER, M., EILMANN, B. \& RIGLING, A. 2014. Increased water-use efficiency does not lead to enhanced tree growth under xeric and mesic conditions. New Phytologist 203:94-109.

LLOYD, J. \& FARQUHAR, G. D. 2008. Effects of rising temperatures and [CO2] on the physiology of tropical forest trees. Philosophical Transactions of the Royal Society B: Biological Sciences 363:18111817.

LÜTTGE, U. 2007. Physiological ecology of tropical plants. (Second edition). Springer, Berlin. 456 pp.

MALHI, Y., AMÉZQUITA, F. F., DOUGHTY, C. E., SILVA-ESPEJO, J. E., GIRARDiN, C. A. J., METCALFE, D. B., ARAGÃO, L. E. O. C., HUARACA-QUISPE, L. P., ALZAMORA-TAYPE, I., EGUILUZ-MORA, L., MARTHEWS, T. R., HALLADAY, K., QUESADA, C. A., L, R. A., FISHER, J. B., ZARAGOZA-CASTELLS, J., ROJAS-VILLAGRA, C. M., PELAEZ-TAPIA, Y., SALINAS, N., MEIR, P. \& PHILLIPS, O. L. 2014. The productivity, metabolism and carbon cycle of two lowland tropical forest plots in south-western Amazonia, Peru. Plant Ecology and Diversity 7:1-21.

MALHI, Y., DOUGHTY, C. E., GOLDSMITH, G. R., METCALFE, D. B., GIRARDIN, C. A. J., MARTHEWS, T. R., DEL AGUILA-PASQUEL, J., ARAgÃO, L. E. O. C., ARAUJO-MURAKMI, A., BRANDO, P., DA COSTA, A. C. L., SILVA-ESPEJO, J. E., FARFÁN AMÉZQUITA, F., GALBRAITH, D. R., QUESADA, C. A., ROCHA, W., SALINASREVILLA, N., SILVÉRIO, D., MEIR, P. \& PHILLIPS, O. L. 2015. The linkages between photosynthesis, productivity, growth and biomass in lowland Amazonian forests. Global Change Biology 21:2283-2295.

MCJANNET, D. P., FITCH, P., DISHER, M. \& WALLACE, J. 2007. Measurements of transpiration in four tropical rainforest types of north Queensland, Australia. Hydrological Processes 21:3549-3564.

MEINZER, F. C., GOLDSTEIN, G., HOLBROOK, N. M., JACKSON, P. \& CAVELIER, J. 1993. Stomatal and environmental control of transpiration in a lowland tropical forest tree. Plant Cell and Environment 16:429-436.

MEINZER, F. C., ANDRADE, J. L., GOLDSTEIN, G., HOLBROOK, N. M., CAVELIER, J. \& JACKSON, P. 1997. Control of transpiration from the upper canopy of a tropical forest: the role of stomatal, boundary layer and hydraulic architecture components. Plant, Cell and Environment 20:1242-1252.

MOSER, G., LEUSCHNER, C., HERTEL, D., GRAEFE, S., SOETHE, N. \& IOST, S. 2011. Elevation effects on the carbon budget of tropical mountain forests (S Ecuador): the role of the belowground compartment. Global Change Biology 17:2211-2226.

MOTZER, T., MUNZ, N., KUPPERS, M., SCHMITT, D. \& ANHUF, D. 2005. Stomatal conductance, transpiration and sap flow of tropical montane rain forest trees in the southern Ecuadorian Andes. Tree Physiology 25:1283-1293.

MUÑOZ-VILLERS, L. E., HOLWERDA, F., GÓMEZ-CÁRDENAS, M., EQUIHUA, M., ASBJORNSEN, H., BRUIJNZEEL, L. A., MARÍNCASTRO, B. E. \& TOBÓN, C. 2012. Water balances of old-growth and regenerating montane cloud forests in central Veracruz, Mexico. Journal of Hydrology 462:53-66.

NAGANO, S., TAKASHI, N., KOUKI, H., NAKANO, T., HIKOSAKA, K. \& MARUTA, E. 2013. Pinus pumila photosynthesis is suppressed by water stress in a wind-exposed mountain site. Arctic Antarctic and Alpine Research 45:229-237.

NEGRET, B. S., PEREZ, F., MARKESTEIJN, L., CASTILLO, M. J. \& ARMESTO, J. J. 2013. Diverging drought-tolerance strategies explain tree species distribution along a fog-dependent moisture gradient in a temperate rain forest. Oecologia 173:625-635.

NOGUEIRA, A., MARTINEZ, C. A., FERREIRA, L. L. \& PRADO, C. H. B. A. 2004. Photosynthesis and water use efficiency in twenty tropical tree species of differing succession status in a Brazilian reforestation. Photosynthetica 42:351-356.

OLIVEIRA, R. S., ELLER, C. B., BITTENCOURT, P. R. L. \& MULLIGAN, M. 2014. The hydroclimatic and ecophysiological basis of cloud forest distributions under current and projected climates. Annals of Botany 113:909-920.

PEÑUELAS, J. \& AZCÓN-BIETO, J. 1992. Changes in leaf $\delta^{13} \mathrm{C}$ of herbarium plant species during the last 3 centuries of $\mathrm{CO}_{2}$ increase. Plant, Cell and Environment 15:485-489.

PEÑUELAS, J., CANADELL, J. G. \& OGAYA, R. 2011. Increased wateruse efficiency during the 20th century did not translate into enhanced tree growth. Global Ecology and Biogeography 20:597-608.

POUNDS, A., FOGDEN, M. P. L. \& CAMPBELL, J. 1999. Biological responses to climate change on a tropical mountain. Nature 398:611-615.

POUNDS, J. A., BUSTAMENTE, M. R., COLOMA, L. A., CONSUEGRA, J. A., FOGDEN, M. P. L., FOSTER, P. N., LA, MARCA, E., MASTERS, K. L., MERINO-VITERI, A., PUSCHENDORF, R., RON, S. R., SÁNCHEZAZOFEIFA, G. A., STILL, C. J. \& YOUNG, B. E. 2006. Widespread amphibian extinctions from epidemic disease driven by global warming. Nature 439:161-167.

RADA, F., GARCÍA-NÚÑEZ, C.\& ATAROFF, M. 2009. Leaf gas exchange in canopy species of a Venezuelan cloud forest. Biotropica 41:659664.

RAICH, J. W., RUSSELL, A. E. \& VITOUSEK, P. M. 1997. Primary productivity and ecosystem development along an elevational gradient on Mauna Loa, Hawai'i. Ecology 78:707-721.

REINHARDT, K. \& SMITH, W. K. 2008. Impacts of cloud immersion on microclimate, photosynthesis and water relations of Abies fraseri (Pursh.) Poiret in a temperate mountain cloud forest. Oecologia 158:229-238.

RICHARDSON, A. D., DENNY, E. G., SICCAMA, T. G. \& LEE, X. 2003. Evidence for a rising cloud ceiling in eastern North America. Journal of Climate 16:2093-2098. 
SANTIAGO, L. S. \& DAWSON, T. E. 2014. Light use efficiency of California redwood forest understory plants along a moisture gradient. Oecologia 174:351-363.

SANTIAGO, L. S., GOLDSTEIN, G., MEINZER, F. C., FOWNES, J. H. \& MUELLER-DOMBOIS, D. 2000. Transpiration and forest structure in relation to soil waterlogging in a Hawaiian montane cloud forest. Tree Physiology 20:673-681.

SAURER, M., SPAHNI, R., FRANK, D. C., JOOS, F., LEUENBERGER, M., LOADER, N. J., MCCARROLL, D., GAGEN, M., POULTER, B. \& SIEGWOLF, R. T. W. 2014. Spatial variability and temporal trends in water-use efficiency of European forests. Global Change Biology 20:3700-3712.

SHERMAN, R. E., FAHEY, T. J., MARTIN, P. H. \& BATTLES, J. J. 2012. Patterns of growth, recruitment, mortality and biomass across an altitudinal gradient in a neotropical montane forest, Dominican Republic. Journal of Tropical Ecology 28:483-495.

SLOT, M., WRIGHT, S. J. \& KITAJIMA, K. 2013. Foliar respiration and its temperature sensitivity in trees and lianas: in situ measurements in the upper canopy of a tropical forest. Tree Physiology 33:505-515.

SOBRADO, M. A. 2003. Hydraulic characteristics and leaf water use efficiency in trees from tropical montane habitats. Trees 17:400-406.

STILL, C. J., FOSTER, P. N. \& SCHNEIDER, H. 1999. Simulating the effects of climate change on tropical montane cloud forests. Nature 398:608-610.

STILL, C. J., RILEY, W. J., BIRAUD, S. C., NOONE, D. C., BUENNING, N. H., RANDERSON, J. T., TORN, M. S., WELKER, J., WHITE, J. W. C., VACHON, R., FARQUHAR, G. D. \& BERRY, J. A. 2009. Influence of clouds and diffuse radiation on ecosystem-atmosphere $\mathrm{CO}_{2}$ and $\mathrm{CO}^{18} \mathrm{O}$ exchanges. Journal of Geophysical Research 114:G01018.

TANAKA, K., TAKIZAWA, H., TANAKA, H., KOSAKA, I., YOSHIFUJI, N., TANTASIRIN, C., PIMAN, S., SUZUKI, M. \& TANGTHAM, N. 2003. Transpiration peak over a hill evergreen forest in northern Thailand in the late dry season: assessing the seasonal changes in evapotranspiration using a multilayer model. Journal of Geophysical Research 108(D17):4533.

TANAKA, N., KURAJI, K., TANTASIRIN, C., TAKIZAWA, H., TANGTHAM, N. \& SUZUKI, M. 2011. Relationships between rainfall, fog and throughfall at a hill evergreen forest site in northern Thailand. Hydrological Processes 25:384-391.

TANNER, E. V. J. 1980. Studies on the biomass and productivity in a series of montane rain forests in Jamaica. Journal of Ecology 68:573588.

URBAN, O., JANOUŠ, D., ACOSTA, M., CZERNÝ, R., MARKOVA, I., NAVRATIL, M., PAVELKA, M., POKORNÝ, R., ŠPRTOVÁ, M. \& ZHANG, R. 2007. Ecophysiological controls over the net ecosystem exchange of mountain spruce stand. Comparison of the response in direct vs. diffuse solar radiation. Global Change Biology 13:157-168.

URBAN, O., KLEM, K., AČ, A., HAVRÁNKOVÁ, K., HOLIŠOVÁ, P., NAVRATIL, M., ZITOVÁ, M., KOZLOVÁ, K., POKORNÝ, R., ŠPRTOVÁ, M., TOMÁŠKOVÁ, I., ŠPUNDA, V. \& GRACE, J. 2012. Impact of clear and cloudy sky conditions on the vertical distribution of photosynthetic $\mathrm{CO}_{2}$ uptake within a spruce canopy. Functional Ecology 26:46-55.

URRUTIA, R. \& VUILLE, M. 2009. Climate change projections for the tropical Andes using a regional climate model: temperature and precipitation simulations for the end of the 21st century. Journal of Geophysical Research 114:D02108.

VAN DE WEG, M. J., MEIR, P., GRACE, J. \& ATKIN, O. K. 2009. Altitudinal variation in leaf mass per unit area, leaf tissue density and foliar nitrogen and phosphorus content along an AmazonAndes gradient in Peru. Plant Ecology and Diversity 2:243254.

VAN DE WEG, M. J., MEIR, P., GRACE, J. \& RAMOS, G. D. 2012. Photosynthetic parameters, dark respiration and leaf traits in the canopy of a Peruvian tropical montane cloud forest. Oecologia 168:23-34.

VAN DER SLEEN, P., GROENENDIJK, P., VLAM, M., ANTEN, N. P. R., BOOM, A., BONGERS, F., PONS, T. L., TERBURG, G. \& ZUIDEMA, P. A. 2015. No growth stimulation of tropical trees by 150 years of $\mathrm{CO}_{2}$ fertilization but water-use efficiency increased. Nature Geoscience $8: 24-28$.

VANDERWEL, M. C., SLOT, M., LICHTSTEIN, J. W., REICH, P. B., KATTGE, J., ATKIN, O. K., BLOOMFIELD, K. J., TJOELKER, M. G. \& KITAJIMA, K. 2015. Global convergence in leaf respiration from estimates of thermal acclimation across time and space. New Phytologist 207:1026-1037.

VARGAS, G. G. \& CORDERO, R. A. 2013. Photosynthetic responses to temperature of two tropical rainforest tree species from Costa Rica. Trees - Structure and Function 27:1261-1270.

VASEY, M. C., LOIK, M. E. \& PARKER, T. V. 2012. Influence of summer marine fog and low cloud stratus on water relations of evergreen woody shrubs (Arctostaphylos: Ericaceae) in the chaparral of central California. Oecologia 170:325-337.

WANG, H., HALL, C. A. S., SCATENA, F. N., FETCHER, N. \& WU, W. 2003. Modeling the spatial and temporal variability in climate and productivity across the Luquillo Mountains, Puerto Rico. Forest Ecology and Management 179:69-94.

WEAVER, P. L. \& MURPHY, P. G. 1990. Forest structure and productivity in Puerto Rico's Luquillo Mountains. Biotropica 22:6982.

WEAVER, P. L., MEDINA, E., POOL, D., DUGGER, K., GONZALES-LIBOY, J. \& CUEVAS, E. 1986. Ecological observations in the dwarf cloud forest of the Luquillo Mountains in Puerto Rico. Biotropica 18:7985.

WHITMORE, T. C. 1998. An introduction to tropical rain forests. Oxford University Press, Oxford. 296 pp.

WILLIAMS, J. W., JACKSON, S. T. \& KUTZBACH, J. E. 2007. Projected distributions of novel and disappearing climates by $2100 \mathrm{AD}$. Proceedings of the National Academy of Sciences USA 104:57385742.

WITTICH, B., HORNA, V., HOMEIER, J. \& LEUSCHNER, C. 2012. Altitudinal change in the photosynthetic capacity of tropical trees: a case study from Ecuador and a pantropical literature analysis. Ecosystems 15:958-973.

WÜRTH, M. K. R., PELÁEZ-RIEDL, S., WRIGHT, S. J. \& KÖRNER, C. 2005. Non-structural carbohydrate pools in a tropical forest. Oecologia 143:11-24.

ZOTZ, G., TYREE, M. T., PATINO, S. \& CARLTON, M. R. 1998. Hydraulic architecture and water use of selected species from a lower montane forest in Panama. Trees - Structure and Function 12:302-309. 
Appendix 1. Sap flow observed in tropical montane cloud forests.

\begin{tabular}{|c|c|c|c|c|c|c|}
\hline $\begin{array}{l}\text { Sap flow } \\
\quad\left(\mathrm{cm} \mathrm{h}^{-1}\right)\end{array}$ & $\begin{array}{l}\text { Volumetric sap flow } \\
\qquad\left(\mathrm{L} \mathrm{d}^{-1}\right)\end{array}$ & $\begin{array}{l}\text { Elevation } \\
\text { (m asl) }\end{array}$ & $\begin{array}{c}\text { Precipitation } \\
\left(\mathrm{mm} \mathrm{y}^{-1}\right)\end{array}$ & Temp. $\left({ }^{\circ} \mathrm{C}\right)$ & Location & Study \\
\hline- & $0.7-2.0$ & 1500 & 3000 & 17.2 & Costa Rica & Feild \& Holbrook (2000) \\
\hline $3.3-5.0$ & & 1950-1975 & 2067 & 15.5 & Ecuador & Motzer et al. (2005) \\
\hline $\begin{array}{l}\text { Montane: } 0.7-1.4 \pm \\
\quad 0.3 \text { (SD), } \\
\text { Premontane: } \\
0.5-1.5 \pm 0.2 \\
(\mathrm{SD})^{*}\end{array}$ & & $1409-1563$ & 2983-3994 & - & Costa Rica & Goldsmith et al. (2013) \\
\hline \multirow[t]{2}{*}{$1.5 \pm 0.5(\mathrm{SE})$} & $\begin{array}{c}\text { Forest line: } 24.7 \pm 5.9 \\
\text { (SE), Cloud forest: } \\
10.7 \pm 3.7(\mathrm{SE})\end{array}$ & $2109-2231$ & $3500-5000$ & 10.5 & Maui (USA) & Gotsch et al. (2014a) \\
\hline & $\begin{array}{c}\text { Branch-level: } 1.8 \pm 0.4 \\
\text { (SE) }\end{array}$ & 2100 & $2000-3000$ & 14.3 & Mexico & Gotsch et al. (2014b) \\
\hline \multirow[t]{2}{*}{$3.3-5.0$} & & $1950-1975$ & 2067 & 15.5 & Ecuador & Motzer et al. (2005) \\
\hline & $\sim 18.75$ & 1560 & 8100 & - & Australia & McJannet et al. (2007) \\
\hline
\end{tabular}

*Understorey branches. 